\title{
Distribution of Fe isotopes in particles and colloids in the salinity gradient along the Lena River plume, Laptev Sea
}

\author{
Sarah Conrad ${ }^{1}$, Johan Ingri ${ }^{1}$, Johan Gelting ${ }^{1}$, Fredrik Nordblad ${ }^{1}$, Emma Engström ${ }^{1,2}$, Ilia Rodushkin ${ }^{1,2}$, \\ Per S. Andersson ${ }^{3}$, Don Porcelli ${ }^{4}$, Örjan Gustafsson ${ }^{5}$, Igor Semiletov ${ }^{6,7,8}$, and Björn Öhlander ${ }^{1}$ \\ ${ }^{1}$ Department of Chemical Engineering and Geosciences, Luleå University of Technology, Luleå, Sweden \\ ${ }^{2}$ ALS Laboratory Group, ALS Scandinavia AB, Aurorum 10, Luleå, Sweden \\ ${ }^{3}$ Department of Geosciences, Swedish Museum of Natural History, Stockholm, Sweden \\ ${ }^{4}$ Department of Earth Sciences, Oxford University, Oxford, UK \\ ${ }^{5}$ Department of Environmental Science and Analytical Chemistry, Stockholm University, Stockholm, Sweden \\ ${ }^{6}$ International Arctic Research Center (IARC), University of Alaska, Fairbanks, AK, USA \\ ${ }^{7}$ Pacific Oceanological Institute (POI), Far Eastern Branch of the Russian Academy of Sciences (FEBRAS), \\ Vladivostok, Russia \\ ${ }^{8}$ Tomsk National Research Politechnical University, Arctic Seas Carbon International Research Laboratory, Tomsk, Russia
}

Correspondence: Sarah Conrad (sarah.conrad@ltu.se)

Received: 10 April 2018 - Discussion started: 26 April 2018

Revised: 27 February 2019 - Accepted: 12 March 2019 - Published: 28 March 2019

\begin{abstract}
Riverine Fe input is the primary Fe source for the ocean. This study is focused on the distribution of Fe along the Lena River freshwater plume in the Laptev Sea using samples from a $600 \mathrm{~km}$ long transect in front of the Lena River mouth. Separation of the particulate $(>0.22 \mu \mathrm{m})$, colloidal $(0.22 \mu \mathrm{m}-1 \mathrm{kDa})$, and truly dissolved $(<1 \mathrm{kDa})$ fractions of Fe was carried out. The total Fe concentrations ranged from 0.2 to $57 \mu \mathrm{M}$ with Fe dominantly as particulate Fe. The loss of $>99 \%$ of particulate Fe and about $90 \%$ of the colloidal Fe was observed across the shelf, while the truly dissolved phase was almost constant across the Laptev Sea. Thus, the truly dissolved Fe could be an important source of bioavailable Fe for plankton in the central Arctic Ocean, together with the colloidal Fe. Fe-isotope analysis showed that the particulate phase and the sediment below the Lena River freshwater plume had negative $\delta^{56} \mathrm{Fe}$ values (relative to IRMM-14). The colloidal Fe phase showed negative $\delta^{56} \mathrm{Fe}$ values close to the river mouth (about $-0.20 \%$ ) and positive $\delta^{56} \mathrm{Fe}$ values in the outermost stations (about $+0.10 \%$ ).

We suggest that the shelf zone acts as a sink for Fe particles and colloids with negative $\delta^{56} \mathrm{Fe}$ values, representing chemically reactive ferrihydrites. The positive $\delta^{56} \mathrm{Fe}$ values of the colloidal phase within the outer Lena River freshwater plume might represent Fe oxyhydroxides, which remain in
\end{abstract}

the water column, and will be the predominant $\delta^{56} \mathrm{Fe}$ composition in the Arctic Ocean.

\section{Introduction}

The cycling of $\mathrm{Fe}$ is a key component for understanding water quality and biogeochemical processes. Iron is the fourth most abundant element in the continental crust (Wedepohl, 1995). The concentration in seawater is low compared to riverine input (Martin and Gordon, 1991). The riverine input of $\mathrm{Fe}$ is one of the most important contributions to the oceanic Fe budget, as well as aeolian dust, recycled sediment, subglacial and iceberg meltwater, and hydrothermal fluxes (Raiswell and Canfield, 2012). Estimations of filterable Fe $(<0.45 \mu \mathrm{m})$ fluxes to the global ocean reveal that about 140 of a maximum of $4800 \mathrm{Gg} \mathrm{yr}^{-1}$ is delivered by rivers (de Baar and de Jong, 2001; Tagliabue et al., 2010). Particulate Fe supplied by rivers to the oceans is 3 orders of magnitude higher than filterable Fe (Martin and Meybeck, 1979). Iron behaves non-conservatively during the mixing of freshwater and seawater and is removed to sediments (Boyle et al., 1977; Eckert and Sholkovitz, 1976; Gustafsson et al., 2000; Sholkovitz, 1978, 1976), since Fe-rich particles and 
colloids flocculate and settle in this mixing zone (Sholkovitz, 1978).

It has been recognized that dissolved $\mathrm{Fe}$ is related to dissolved organic carbon (DOC) in freshwater (Perdue et al., 1976) and so, to investigate the pathways for organic carbon (OC) in the Arctic, knowledge about Fe cycling and the coupling between the boreal-Arctic watershed and the Arctic basin is crucial. Iron and OC in water samples can be separated using a variety of filtration techniques. These include both membrane filtration $(0.22$ to $0.7 \mu \mathrm{m})$ and ultrafiltration $(1,10$, or $30 \mathrm{kDa})$ and size fractions are thus often operationally defined as particulate matter (larger than 0.22 or $0.7 \mu \mathrm{m}$ ), colloidal (smaller than particles but do not pass an ultrafilter), and truly dissolved phases (passing through an ultrafilter). Due to the technical complexity with ultrafiltration, including the extensive filtration time, there are few ultrafiltration Fe data available (Guo and Santschi, 1996; Ingri et al., 2000; Pokrovsky et al., 2012). Truly dissolved Fe data are scarce and deliver insights into this part of the $\mathrm{Fe}$ pool.

Previous studies showed that there is a relationship between $\mathrm{Fe}$ and $\mathrm{OC}$ in the dissolved fraction and found two main forms of $\mathrm{Fe}$ compounds: $\mathrm{Fe}-\mathrm{OC}$ and $\mathrm{Fe}$ oxyhydroxides (Escoube et al., 2015; Hirst et al., 2017b; Ilina et al., 2013; Ingri et al., 2006, 2000; Kritzberg et al., 2014; Pokrovsky et al., 2010, 2006; Pokrovsky and Schott, 2002; Raiswell and Canfield, 2012; Stolpe et al., 2013). It has also been shown that humic substances (HSs) are associated with newly formed $\mathrm{Fe}$ oxyhydroxides in freshwater (Pédrot et al., 2011; Tipping, 1981). The behaviour of these $\mathrm{Fe}$ and OC particles and colloids during estuarine mixing depend on their chemical reactivity, which is defined by their size and speciation (Poulton and Raiswell, 2005; Tagliabue et al., 2017). Hirst et al. (2017b) found that about $70 \%$ of the total suspended Fe in the Lena River is in the form of reactive ferrihydrite. These ferrihydrites are independent particles within a network of amorphous particulate OC (POC) and are attached to the surfaces of primary organic matter and clay particles (Hirst et al., 2017b).

Carbon-iron cycling is complex, and stable Fe-isotope data show that the isotopic compositions might be used to investigate chemical pathways for $\mathrm{Fe}$ and $\mathrm{Fe}$ bound to $\mathrm{OC}$ during weathering and estuarine mixing in the boreal-Arctic region (Dos Santos Pinheiro et al., 2014; Escoube et al., 2015, 2009; Ilina et al., 2013; Ingri et al., 2006; Mulholland et al., 2015; Poitrasson, 2006; Poitrasson et al., 2014). The ${ }^{56} \mathrm{Fe} /{ }^{54} \mathrm{Fe}$ and ${ }^{57} \mathrm{Fe} /{ }^{54} \mathrm{Fe}$ ratios are defined relative to the international reference material IRMM-14 and are expressed as deviations from the standard in parts per thousand, or $\delta$ notation (in per mille \%o), as

$\delta^{56} \mathrm{Fe}=\left[\frac{\left({ }^{56} \mathrm{Fe} /{ }^{54} \mathrm{Fe}\right)_{\text {sample }}}{\left({ }^{56} \mathrm{Fe} /{ }^{54} \mathrm{Fe}\right)_{\text {IRMM-14 }}}-1\right] \times 10^{3}$ $\delta^{57} \mathrm{Fe}=\left[\frac{\left({ }^{57} \mathrm{Fe} /{ }^{54} \mathrm{Fe}\right)_{\text {sample }}}{\left({ }^{57} \mathrm{Fe} /{ }^{54} \mathrm{Fe}\right)_{\text {IRMM-14 }}}-1\right] \times 10^{3}$.

Using this definition, the continental crust has a $\delta^{56} \mathrm{Fe}$ value of $0.07 \pm 0.02 \%$ (Poitrasson, 2006). In low-temperature environments the $\delta^{56} \mathrm{Fe}$ can vary by about $5 \%$ (Anbar, 2004; Beard et al., 2003; Fantle and DePaolo, 2004; Rouxel et al., 2005). The variations in $\delta^{56} \mathrm{Fe}$ can be used to trace different Fe phases in rivers (Dos Santos Pinheiro et al., 2014; Ilina et al., 2013; Ingri et al., 2006; Poitrasson et al., 2014) and to map the origin of $\mathrm{Fe}$ (Conway and John, 2014). Isotope fractionation processes result in a $\delta^{56} \mathrm{Fe}$ value that can be higher or lower compared to the continental crust. The Fe-isotopic composition is impacted by redox reactions (Wiederhold et al., 2006), complexation with organic ligands, and inorganic speciation of $\mathrm{Fe}$, as well as the immobilization of Fe by precipitation and adsorption (Beard et al., 2003, 1999; Beard and Johnson, 2004; Brantley et al., 2001; Bullen et al., 2001; Icopini et al., 2004; Poitrasson and Freydier, 2005; Skulan et al., 2002; Welch et al., 2003). These processes can yield either negative or positive $\delta^{56} \mathrm{Fe}$ values, depending on the initial $\mathrm{Fe}$-isotopic composition and the fractionation factor. Recent studies showed that sub-Arctic and temperate rivers, with high $\mathrm{Fe}$ and $\mathrm{OC}$ concentrations, have low $\delta^{56} \mathrm{Fe}$ values in the particulate phase, while the dissolved phase has high $\delta^{56} \mathrm{Fe}$ (Escoube et al., 2015, 2009; Ilina et al., 2013; Ingri et al., 2006; Rouxel et al., 2008; Severmann et al., 2006). Also, high $\delta^{56} \mathrm{Fe}$ values have been reported in the low molecular weight (LMW) fraction $(<10 \mathrm{kDa})$, while colloids and particles showed high $\delta^{56} \mathrm{Fe}$ values (Ilina et al., 2013). Furthermore, seasonal variations in the Fe-isotopic composition and $\mathrm{Fe}$ speciation have been reported (Allard et al., 2004; Escoube et al., 2015; Ingri et al., 2006).

This study presents Fe concentrations and Fe-isotope compositions in the particulate and colloidal phase along the Lena River freshwater plume in the Laptev Sea, as well as Fe concentrations in the truly dissolved phase. The Lena RiverLaptev Sea transect is stratified, with a freshwater layer that is on top of more saline, dense, deep waters and plays an important role in the transport of $\mathrm{Fe}$ and the distribution of $\mathrm{Fe}$ isotopes in the Arctic Ocean. The main objectives were to study the distribution of $\mathrm{Fe}$ in the Lena River-Laptev Sea transect and the variations in the partitioning of Fe between the different size fractions, as well as to identify the impact of processes such as mixing, transformation, and removal by settling on the export of Fe to the deeper ocean. Furthermore, $\mathrm{Fe}$-isotope analysis of the colloidal and particulate fraction should help us to gain a better understanding of the composition of Fe particles and colloids transported out in the Arctic Ocean. 


\section{Sampling site and analytical methods}

\subsection{Study area}

The Lena River is $4387 \mathrm{~km}$ long and has the eighth largest discharge in the world. It is the second largest river draining into the Arctic Ocean and flows into the Laptev Sea (Fig. 1). The Lena watershed covers an area of $2.46 \times 10^{6} \mathrm{~km}^{2}$ (Rachold et al., 1996) and is bound by the Verkhoyansk Mountain Ridge in the northeast and the central Siberian uplands in the west. Larch forests cover $72 \%$ of the watershed area and shrublands about $12 \%$ (Wagner, 1997; Walter and Breckle, 2002). Permafrost underlies $78 \%-93 \%$ of the watershed (Zhang et al., 1999) and extends to depths of up to $1500 \mathrm{~m}$ (Anisimov and Reneva, 2009). The annual discharge to the Arctic Ocean is $581 \mathrm{~km}^{3}$ (Yang et al., 2002). During the spring flood, from late May to June, $31 \%-45 \%$ of the annual run-off occurs (Amon et al., 2012). The Lena River delivers 5.6-5.8 Tg of DOC into the Arctic Ocean annually (Holmes et al., 2012; Raymond et al., 2007), along with about $0.4 \mathrm{Tg}$ of particulate OC (Semiletov et al., 2011). More than $50 \%$ of the total OC (TOC) is delivered during a 2-month period in summer, with 6.6 $\mathrm{Tg} \mathrm{yr}^{-1}$ in June (Le Fouest et al., 2013) and $3.5 \mathrm{Tg} \mathrm{yr}^{-1}$ in July (Kutscher et al., 2017). The run-off from the Lena River accounts for more of $70 \%$ of the overall river inflow to the Laptev Sea (Antonov, 1967). The freshwater plume in the Laptev Sea is a mixing zone of about $600 \mathrm{~km}$ length and $50 \mathrm{~km}$ width (Fig. 2). A low-salinity freshwater plume overlies denser highly saline Arctic seawater (Alling et al., 2010). The Lena River plume can be divided into an inner and an outer plume based on a sharp increase in salinity, with salinities up to 5 in the inner plume and up to 15 in the outer plume (Alling et al., 2010). Both parts of the plume are separated by a strong halocline at about $10 \mathrm{~m}$ depth from the underlying dense Arctic seawater that has salinities up to 35 (Alling et al., 2010; Chester, 2003; Martin et al., 1993).

\subsection{Sampling and processing}

The samples were collected in August 2008 during the International Siberian Shelf Study (ISSS-08) from the RV Yacob Smirnitskyi. The ISSS-08 was part of the International Polar Year (IPY) and the Arctic GEOTRACES programmes. The sampling transect is $600 \mathrm{~km}$ long, stretching from off the Lena River mouth across the Laptev Sea, and samples from ten stations were collected after the GEOTRACES protocol (Figs. 1 and 2 and Table 1), (Cutter et al., 2010). Additionally, surface sediment (upper $2 \mathrm{~cm}$ ) samples were taken from the Kara, Laptev, and East Siberian seas (Fig. 1). Samples from this region collected during this cruise have also been studied for DOC (Alling et al., 2010; Bröder et al., 2016; Karlsson et al., 2016; Salvadó et al., 2017), dissolved inorganic carbon (Alling et al., 2012), POC (Karlsson et al., 2016; SánchezGarcía et al., 2011), nutrients and alkalinity (Anderson et al.,
2009; Pipko et al., 2017), and stable O isotopes (Rosén et al., 2015).

All water samples besides YS-14 were collected between 2.5 and $5.0 \mathrm{~m}$ depth using a peristaltic pump and acidcleaned, silicon tubing. The tubing was attached to a flagpole, which was mounted to the bow of the ship. To avoid contamination from the ship, the flagpole was extended about $10 \mathrm{~m}$ in front of the ship. The samples were pumped into a $25 \mathrm{~L}$ container, which was rinsed with Milli-Q water between each station. Station YS-14 was sampled at $4.0 \mathrm{~m}$ depth using a $60 \mathrm{~L} \mathrm{Go-Flo}{ }^{\circledR}$ water sampler. All equipment in contact with the samples were cleaned with $5 \% \mathrm{HNO}_{3}$, rinsed with Milli$\mathrm{Q}$ water, and dried in a HEPA-filtered clean-air hood. Membrane filtration was carried out within $12 \mathrm{~h}$ of sampling. All water samples were stored in acid-cleaned polyethylene (PE) bottles and acidified with ultrapure $\mathrm{HNO}_{3}$ to a $\mathrm{pH}<2$, and all nitrocellulose filters $\left(0.22 \mu \mathrm{m}\right.$, Millipore $\left.{ }^{\circledR}\right)$ were stored at $-18^{\circ} \mathrm{C}$ until further analysis (Ödman et al., 1999). Samples for POC were filtered with $0.7 \mu \mathrm{m} \mathrm{GF/F}$ glass-fibre filters $\left(\right.$ Whatman $\left.{ }^{\circledR}\right)$. The filters were pre-combusted for $4 \mathrm{~h}$ at $450{ }^{\circ} \mathrm{C}$ to limit the $\mathrm{C}$ blank.

Sediment samples were taken with a GEMAX gravity corer and a Van Veen grab sampler as described earlier (Vonk et al., 2012).

During cross-flow ultrafiltration the sample water $(<$ $0.22 \mu \mathrm{m}$ ) flows across a membrane surface at a constant pressure. This process prevents clogging, while particles smaller than the membrane cut-off can pass, larger suspended particles remain circulating in the sample water. The sample water progressively decreases in volume as the permeate crosses the filter, and the larger colloids and particles remain in the retentate, which is therefore progressively concentrated. The cross-flow ratio $\left(\mathrm{CFR}=Q_{\mathrm{R}} / Q_{\mathrm{P}}\right.$, where $Q_{\mathrm{R}}$ and $Q_{\mathrm{P}}$ are the flow rates of the retentate and permeate, respectively) (Forsberg et al., 2006; Ingri et al., 2000; Larsson et al., 2002) was kept between 60 and 100 to achieve an overall concentration factor larger than 10: $\left(V_{\mathrm{P}}+V_{\mathrm{R}}\right) / V_{\mathrm{R}}$, where $V_{\mathrm{P}}$ and $V_{\mathrm{R}}$ are the final volumes of the permeate and retentate, respectively. For the concentration factors and cross-flow ratios; see Table 2. In this study, the water used for ultrafiltration was pre-filtered through a membrane $(<0.22 \mu \mathrm{m})$ prior to introduction into the MilliPore ${ }^{\circledR}$ Prep/Scale ultrafiltration system, which had a cut-off of $1 \mathrm{kDa}$. Thus, the permeate is $<1 \mathrm{kDa}$, while the retentate includes colloids between $<0.22 \mu \mathrm{m}$ and $1 \mathrm{kDa}$.

\subsection{Analytical methods}

Iron concentrations and isotopic compositions were measured at ALS Scandinavia AB. All sample manipulations were performed in a clean laboratory (class 10000) by personnel wearing clean-room gear and following all general precautions to reduce contamination (Rodushkin et al., 2010). High-purity Suprapure ${ }^{\circledR}$ acids were used throughout sample treatment and analysis. Organic carbon analyses were 


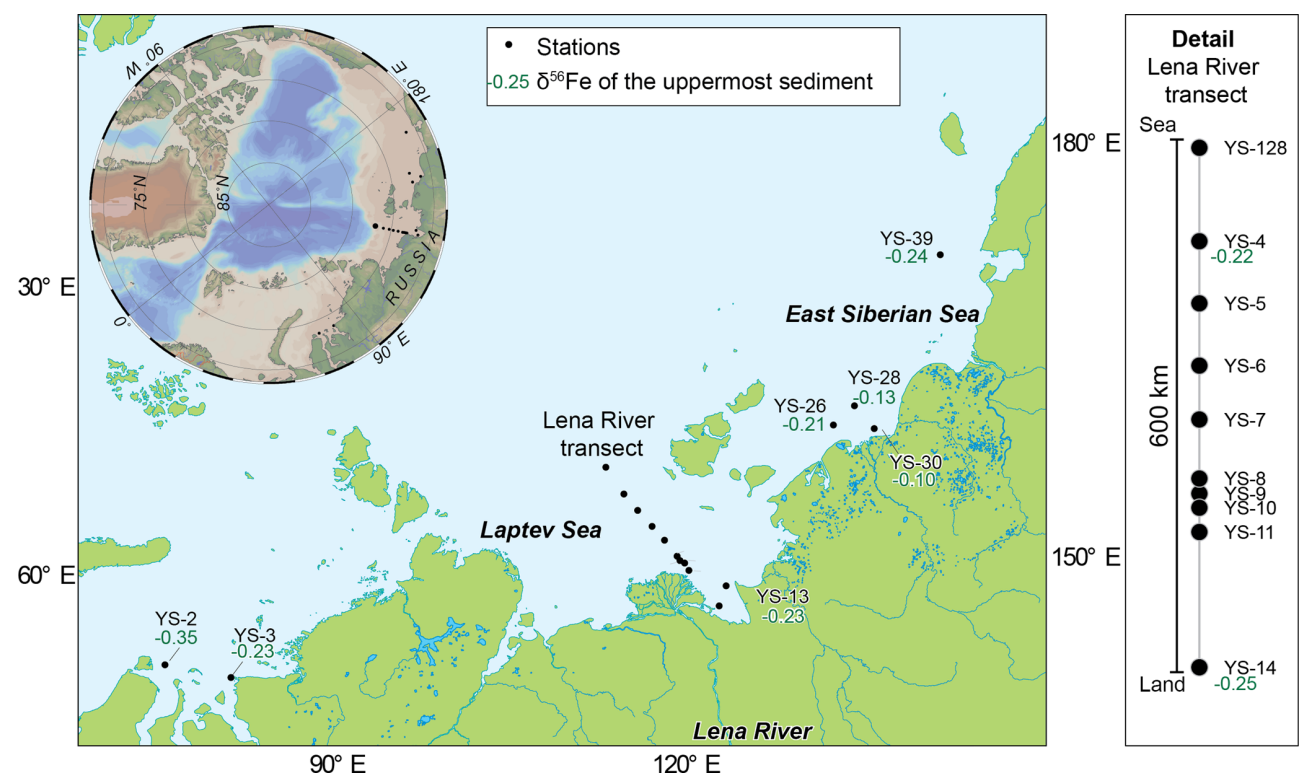

Figure 1. Sampling stations in the Arctic Ocean. Black dots mark the stations on the detailed East Siberian Arctic Shelf map. Along the Lena River-Laptev Sea transect, membrane filtration and/or ultrafiltration was carried out. The sampling stations of this study follow the Lena River freshwater plume. The green numbers display $\delta^{56} \mathrm{Fe}$ values measured in the uppermost sediment.

Table 1. Sampling stations in the Laptev Sea of the ISSS-08 research cruise. Temperature, salinity, pH, and oxygen data for the Lena River freshwater plume are obtained from water at a depth of $4 \mathrm{~m}$, whereas the data for the shelf sediment sample locations are obtained from the overlying bottom waters. The measurements were done with a CTD Seabird 19+. Salinity is based on the Practical Salinity Scale PSS-78.

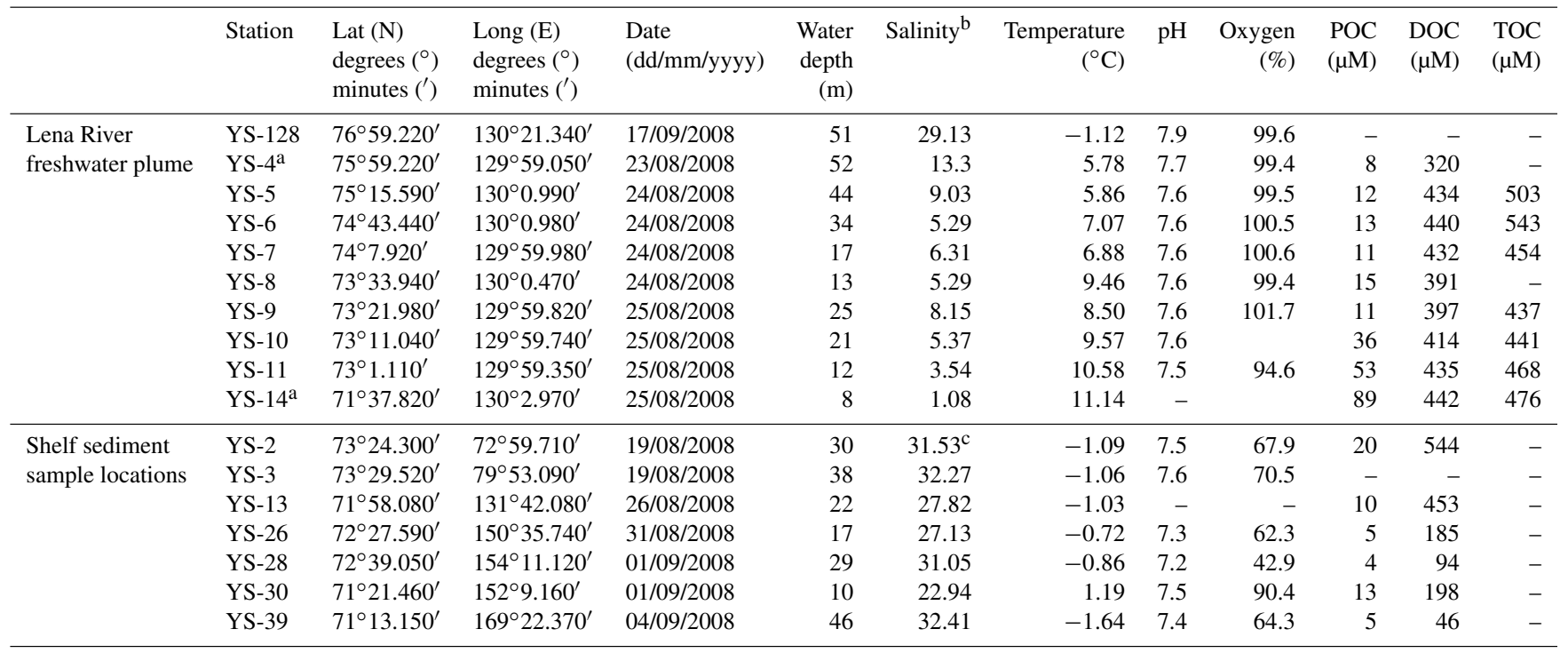

${ }^{a}$ Station was also sampled for surface sediment. ${ }^{\mathrm{b}}$ Salinity, $\mathrm{pH}$, and oxygen saturation for shelf sediment samples are measured in bottom water. ${ }^{\mathrm{c}}$ Measured with a Hydrosonde M5.

carried out at Stockholm University (for analytical details; see Alling et al., 2010; Sánchez-García et al., 2011).

For element analysis, the water samples (colloidal: $1 \mathrm{kDa}$ to $0.22 \mu \mathrm{m}$; truly dissolved: $<1 \mathrm{kDa})$ were diluted $(2-200$ fold) with $10 \% \mathrm{HNO}_{3}$. The degree of dilution was dependent on the salinity of the sample. At least two dilutions of each sample were carried out: one high dilution for determination of major elements and one low dilution for minor and trace elements. For $\mathrm{Fe}$ analysis, the samples were diluted by a factor of 50. In order to analyse the particles on the filters, the filters were treated with a $1000: 1$ mixture of $\mathrm{HNO}_{3}: H F$ overnight, followed by closed-vessel microwave-assisted digestion. Prior to analysis, the digests were further diluted in $10 \% \mathrm{HNO}_{3}$. 
Table 2. Cross-flow ultrafiltration details.

\begin{tabular}{lrrrrrr}
\hline Sample & $\begin{array}{r}\text { Retentate } \\
\left(V_{\mathrm{R}}\right) \text { litre }\end{array}$ & $\begin{array}{r}\text { Permeate } \\
\left(V_{\mathrm{P}}\right) \text { litre }\end{array}$ & $\begin{array}{r}\text { Concentration } \\
\text { factor }\end{array}$ & $\begin{array}{r}\text { Retentate } Q_{\mathrm{R}} \\
\left(\mathrm{mL} \mathrm{min}^{-1}\right)\end{array}$ & $\begin{array}{r}\text { Permeate } Q_{\mathrm{P}} \\
\left(\mathrm{mL} \mathrm{min}^{-1}\right)\end{array}$ & $\begin{array}{r}\text { Cross-flow } \\
\text { ratio }(\mathrm{CFR})\end{array}$ \\
\hline YS-128 & 0.97 & 16.4 & 18 & $>3000$ & $30-50$ & $60-100$ \\
YS-4 & 1.14 & 11.8 & 11 & 3000 & 30 & 100 \\
YS-11 & 1.10 & 10.5 & 11 & $>3000$ & $30-50$ & $60-100$ \\
YS-14 & 0.61 & 12.2 & 21 & $>3000$ & $30-50$ & $60-100$ \\
\hline
\end{tabular}

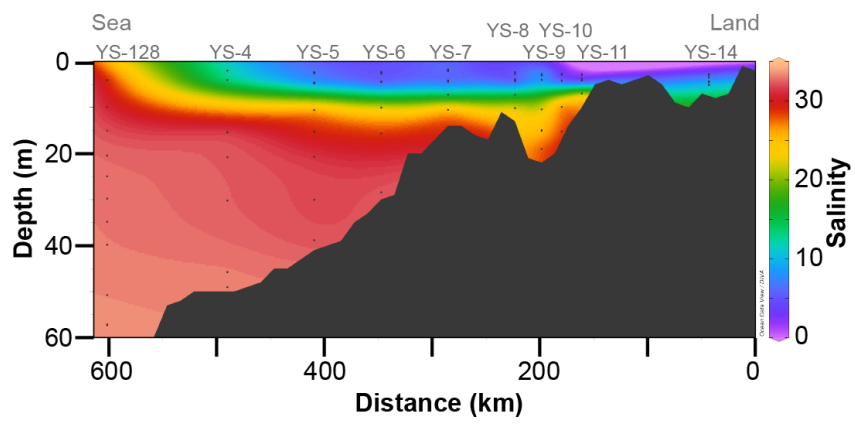

Figure 2. The salinity gradient along the Lena River-Laptev Sea transect. Salinity is based on the Practical Salinity Scale PSS-78. The freshwater builds an almost $10 \mathrm{~m}$ thick surface layer in the Laptev Sea, and the plume itself extends over an area of about $50 \times 600 \mathrm{~km}$. The plume is divided into an inner and outer plume between stations YS-8 and YS-11 by a sharp increase in salinity.

Multi-elemental analysis of the water and filter samples was performed on an inductively coupled plasma sector field mass spectrometer (ICP-SFMS, ELEMENT2 Thermo Scientific) at ALS Scandinavia AB. The measurement procedure combines internal standardization and external calibration. For internal standardization, indium was added to all the solutions (Rodushkin et al., 2005; Rodushkin and Ruth, 1997). The analytical procedure was validated with different reference materials (SLRS-4 river water CRM for trace metals, SLEW-2 estuarine water CRM for trace metals, and NASS4 open ocean water - all supplied from National Research Council, Ottawa, Canada) (Rodushkin et al., 2005, 2016).

The blanks of digested filters $(0.22 \mu \mathrm{m})$ for $\mathrm{Fe}$ were $2.79 \mu \mathrm{g} \mathrm{L}-1$, which is about $0.25 \%$ of the average Fe concentration in the samples for the Lena River sampling transect. Replicated measurements of sample concentrations showed a precision of $\pm 3 \%(n=4)$. The limit of detection for $\mathrm{Fe}$ in seawater (salinity 35 ) is $250 \mathrm{ppt}$, the salinity levels in the analysed samples were much lower, which decreases the limit of detection. Fe concentrations for the particulate, colloidal, and truly dissolved phases are reported in Table 3. Aluminum and titanium concentrations can be found in the Supplement.
For the Fe-isotope ratio measurements, water samples (colloidal: $1 \mathrm{kDa}$ to $0.22 \mu \mathrm{m}$ ) and digested filters were evaporated to dryness, and the residue was redissolved in $1 \mathrm{~mL}$ $9 \mathrm{M} \mathrm{HCl}$. Iron was separated from the matrix elements by using an AG-MP-1M ion-exchange resin (Ingri et al., 2006; Rodushkin and Ruth, 1997). After the sample was loaded, the matrix was washed with $9.6 \mathrm{M} \mathrm{HCl}$, and $\mathrm{Cu}$ was eluted with $8 \mathrm{~mL} 5 \mathrm{M} \mathrm{HCl}$. Afterwards, Fe was eluted with $6 \mathrm{~mL} 2 \mathrm{M} \mathrm{HCl}$ and can be used for further steps (Rodushkin et al., 2016). After evaporating to dryness, $50 \mu \mathrm{L}$ of concentrated $\mathrm{HNO}_{3}$ was pipetted directly to the residue, followed by the addition of $5 \mathrm{~mL}$ of Milli-Q water. Samples with high Fe content were diluted with $0.2 \mathrm{MHNO}_{3}$ to a concentration of $2 \mathrm{mg} \mathrm{L}^{-1}$ in the measurement solutions. Low Fe concentration water samples were further diluted to $40-50 \mu \mathrm{g} \mathrm{L}^{-1}$ and measured using high-efficiency desolvation nebulizer (Aridus) in a separate analytical sequence. Iron was separated from the matrix by ion exchange, with a recovery rate above $95 \%$. The Fe-isotope compositions in separated fractions from filters and water samples were measured using a multicollector inductively coupled plasma mass spectrometer (MC-ICP-MS, NEPTUNE PLUS ${ }^{\circledR}$, Thermo Scientific) equipped with micro-concentric nebulizer and tandem cyclonic Scott double-pass spray chamber. Instrumental mass biases were corrected by sample-standard bracketing using IRMM-14 CRM, while an internal standard (Ni) was added to all samples and used to correct for instrumental drift. Each sample was measured twice with the sample-standard bracketing method. Detailed information on the correction procedures can be found in Baxter et al. (2006). During the Fe-isotope analysis, $\delta^{56} \mathrm{Fe}$ and $\delta^{57} \mathrm{Fe}$ were measured. In the three-isotope plot of $\delta^{56} \mathrm{Fe}$ and $\delta^{57} \mathrm{Fe}$, all samples are plotted on a single mass fractionation line (Fig. S1 in the Supplement). We only discuss the $\delta^{56} \mathrm{Fe}$ in this study, although all Fe-isotope data are reported in Table 4, including $2 \sigma(n=4)$.

\section{Results}

The average $\mathrm{pH}$ for the water samples was $7.6 \pm 0.1$ (1 SD) and the oxygen saturation was $99.4 \pm 2.1 \%$ (Table 1), (Andersson and Jutterstrøm, 2008). Within the Lena River freshwater plume the $\mathrm{pH}$ ranged from 7.5 to 7.9. The methodology for $\mathrm{pH}$ and oxygen measurements is described in the Supplement (after Dudarev, 2008). 

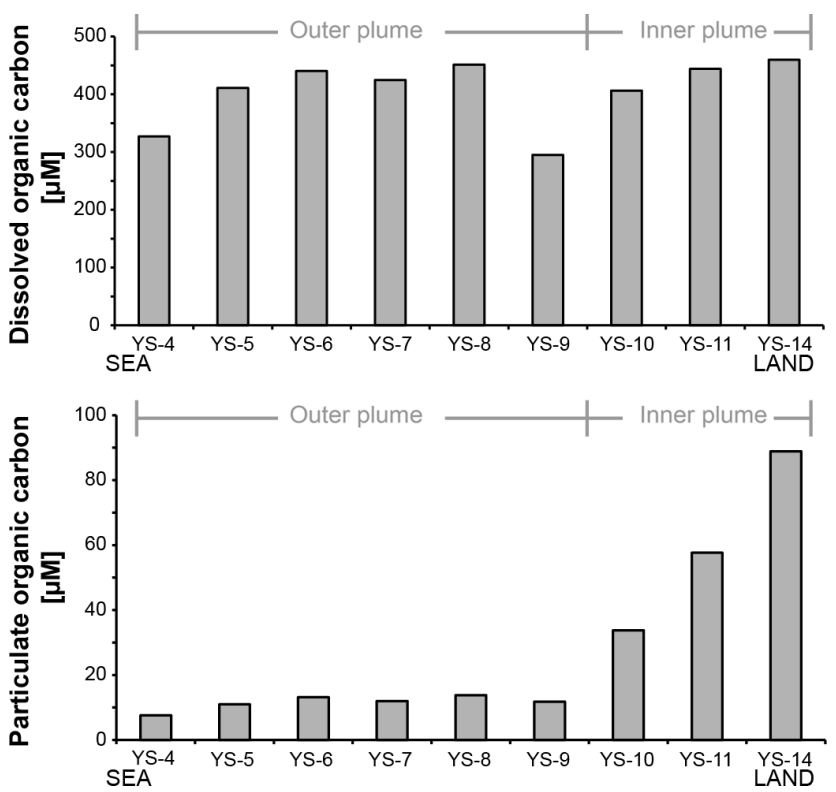

Figure 3. Dissolved $(<0.70 \mu \mathrm{m})$ and particulate $(>0.70 \mu \mathrm{m})$ organic carbon concentrations along the Lena River-Laptev Sea transect. Close to the Lena River mouth, POC constitutes about $18 \%$ of the TOC input, while at the outermost station it is only $2 \%$ of the TOC.

\subsection{Organic carbon distributions in the Lena River plume}

The DOC concentrations show a small variation between 320 and $442 \mu \mathrm{M}$ in the surface waters of the inner and outer plume (Table 1; Fig. 3). The average DOC concentration of $410 \mu \mathrm{M}$ in the surface water of the Lena River freshwater plume has been reported by Alling et al. (2010) and is similar to previous studies (Cauwet and Sidorov, 1996: 300-600 $\mu$ M). It has been shown that DOC is behaving conservatively during mixing between Lena River water and Arctic Ocean water along the sampling profile (Alling et al., 2010; Opsahl et al., 1999; Pugach et al., 2018). The POC concentrations decrease from high values $(89 \mu \mathrm{M})$ close to the coast to low values $(8 \mu \mathrm{M})$ in the outer plume (Fig. 3). In the inner plume (YS-14 to YS10) the POC concentrations are high, between 89 and $36 \mu \mathrm{M}$, whereas in the outer plume the POC concentrations were almost constant, with an average value of about $12 \mu \mathrm{M}$. The overall average POC concentration of about $28 \mu \mathrm{M}$ has been reported earlier by Sánchez-García et al. (2011).

\subsection{Iron concentrations in the Lena River freshwater plume}

Three size fractions were analysed for $\mathrm{Fe}$ : particulate $\mathrm{Fe}$ (PFe; $>0.22 \mu \mathrm{m})$, colloidal Fe (CFe; $1 \mathrm{kDa}-0.22 \mu \mathrm{m})$, and truly dissolved $\mathrm{Fe}(\mathrm{DFe} ;<1 \mathrm{kDa})$. The total $\mathrm{Fe}(\mathrm{TFe})$ concentration was calculated as the sum of $\mathrm{PFe}, \mathrm{CFe}$, and $\mathrm{DFe}$ (Table 3).

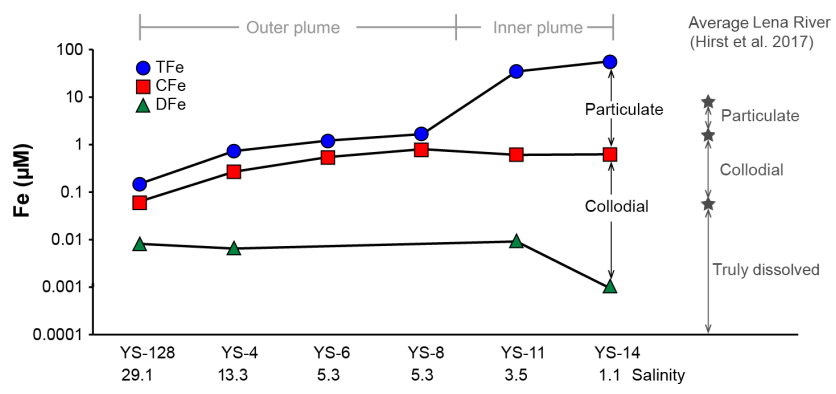

Figure 4. Total, colloidal, and truly dissolved Fe concentrations along the Lena River freshwater plume. Concentrations of PFe and $\mathrm{CFe}$ decreased along the salinity gradient, while the concentrations of DFe are almost constant. Note the logarithmic scale and the sharp decrease in PFe between the inner and the outer plume. The reference for the Lena River is an average of all analysed samples ( $\mathrm{PFe}$ $n=3$; CFe and DFe $n=5$ ) by Hirst et al. (2017b).

The PFe concentration decreased from 56 to $0.1 \mu \mathrm{M}$ along the Lena River freshwater plume (Fig. 4). Between the inner and the outer plumes (i.e. between YS-11 and YS-8), the $\mathrm{PFe}$ concentration dropped to $0.9 \mu \mathrm{M}$, with a loss of $>99 \%$ of PFe. The loss of Fe was estimated as a fraction of the maximum $\mathrm{Fe}$ concentration of each size fraction (details can be found in the Supplement). The CFe concentration decreased from 0.6 to $0.1 \mu \mathrm{M}$ along the freshwater plume, a loss of about $90 \% \mathrm{CFe}$ (Fig. 4). The concentration of DFe was low, at around $8 \mathrm{nM}$, and relatively constant along the plume (Fig. 4). In total, a loss of $>99 \% \mathrm{TFe}$ was observed between the first station (YS-14) and the last station (YS-128).

We observed non-conservative behaviour of $\mathrm{PFe}$ during mixing between Lena River water and Arctic Ocean water, while $\mathrm{CFe}$ showed generally conservative behaviour, with an almost linear correlation with salinity (Fig. 5). The PFe concentrations below $1 \mu \mathrm{M}$ also showed an almost linear correlation at salinities above 5 in the outer plume. In the inner plume, at salinities below 5, the PFe showed nonconservative behaviour.

\subsection{Iron isotopes in the Lena River freshwater plume}

The Fe-isotope compositions in the particulate and the colloidal phases, as well as in the surface sediments, are reported in Fig. 6. The $\delta^{56} \mathrm{Fe}$ values in the particulates varied between $-0.05 \pm 0.11 \%$ o (YS-14) in the inner plume and $-0.41 \pm 0.12 \%$ o (YS-4) in the outer plume (Fig. 6), with the $\delta^{56} \mathrm{Fe}$ values in the outer plume all lower compared to the inner plume. The $\mathrm{CFe}$ show negative $\delta^{56} \mathrm{Fe}$ values (average $-0.20 \pm 0.06 \%$ o) in the inner plume and positive $\delta^{56} \mathrm{Fe}$ values (average $0.11 \pm 0.08 \%$ ) in the outer plume. The surface sediments from the Laptev Sea had negative $\delta^{56} \mathrm{Fe}$ values $(-0.23 \pm 0.08 \%$ and $-0.25 \pm 0.12 \%$ o $)$. Surface sediments obtained from 10 samples in other parts of the East Siberian Arctic Shelf (ESAS) showed only small variations (Figs. 1 and 6; Tables 4 and S2 in the Supplement). 
Table 3. Iron concentrations of the different fractions for the Lena River freshwater plume.

\begin{tabular}{llrrrrr}
\hline Station & Location & $\begin{array}{r}\text { Particulate } \\
\mu \mathrm{M}\end{array}$ & $\begin{array}{r}\text { Colloidal } \\
\mu \mathrm{M}\end{array}$ & $\begin{array}{r}\text { Truly dissolved } \\
\mathrm{nM}\end{array}$ & $\begin{array}{r}\text { Total } \\
\mu \mathrm{M}\end{array}$ & $\begin{array}{r}\mathrm{pFe} / \mathrm{cFe} \\
\mathrm{mol} \mathrm{ratio}\end{array}$ \\
\hline YS-128 & Lena transect; Laptev Sea & 0.1 & 0.1 & 8 & 0.2 & 1 \\
YS-4 & Lena transect & 0.5 & 0.3 & 7 & 0.8 & 2 \\
YS-5 & Lena transect & - & - & - & - & - \\
YS-6 & Lena transect & 0.7 & 0.6 & - & 1.3 & 1 \\
YS-7 & Lena transect & - & - & - & - & - \\
YS-8 & Lena transect & 0.9 & 0.8 & - & 1.7 & 1 \\
YS-9 & Lena transect & - & - & - & - & - \\
YS-10 & Lena transect & - & - & - & - & - \\
YS-11 & Lena transect & 34.0 & 0.6 & 9 & 35.0 & 56 \\
YS-14 & Lena transect; Mohtaba Island & 56.0 & 0.6 & 1 & 57.0 & 90 \\
\hline
\end{tabular}

Total Fe is calculated as a sum of particulate, colloidal, and truly dissolved Fe.

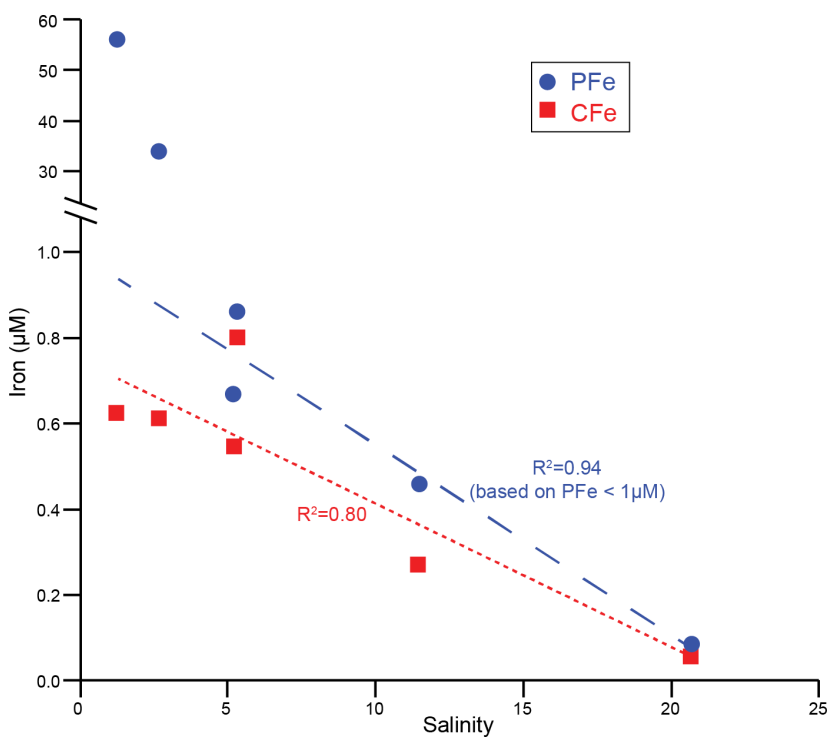

Figure 5. The colloidal and particulate Fe concentrations plotted vs. salinity. Salinity is based on the Practical Salinity Scale PSS78. Note the $y$-axis break due to the high range of PFe in the inner plume. The linear correlation between PFe and salinity is based on the data points below $1 \mu \mathrm{M} \mathrm{PFe}$. In the low-salinity environment, the $\mathrm{PFe}$ is much higher compared to the $\mathrm{CFe}$, whereas at salinities above 5 the differences are smaller.

\section{Discussion}

In the Laptev Sea, close to the river mouth, about $18 \%$ of the total OC was present as POC and this was apparently rapidly lost during mixing (Fig. 3). In the outer plume only about $2 \%$ of the total OC was present as POC. It has been suggested that POC in the Lena River freshwater plume is transported in different forms, including large particles, which can sink, and almost neutrally buoyant flocculates of humic substances (Gustafsson and Gschwend, 1997; Gustafsson et al., 2000; Sánchez-García et al., 2011). The POC, which is as-

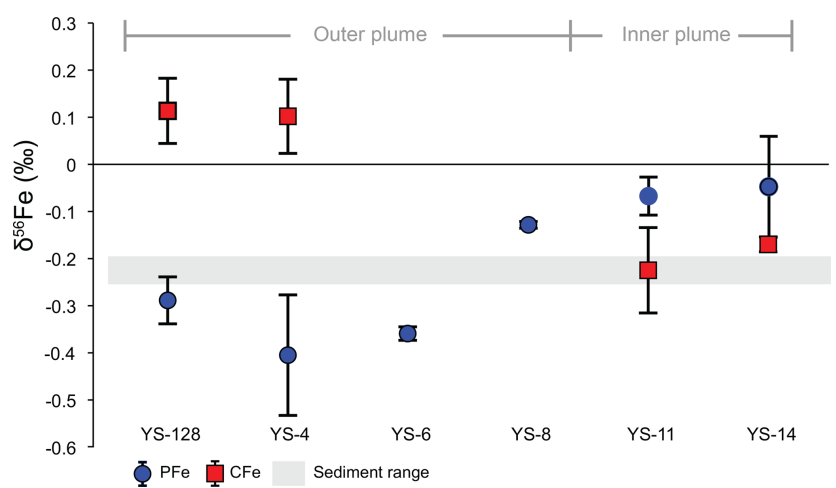

Figure 6. Iron-isotope values along the Lena River freshwater plume and the uppermost sediment of the East Siberian Arctic Shelf (ESAS). The error bars represent $\pm 2 \sigma$. In some cases the symbol is larger than the error. The $\delta^{56} \mathrm{Fe}$ values of PFe are negative at all stations: values close to zero are closer to the coast and more negative ones are towards the open sea. The $\delta^{56} \mathrm{Fe}$ values of the $\mathrm{CFe}$ are negative in the inner plume and positive in the outer plume. The $\delta^{56} \mathrm{Fe}$ of the sediment samples were around $-0.2 \%$, displaying the overall composition of the entire ESAS area.

sociated with larger particles $(>0.7 \mu \mathrm{m})$, will settle close to land, whereas the humic substance flocculates will travel further out (Vonk et al., 2010).

\subsection{Iron behaviour in the Lena River freshwater plume}

The PFe concentrations found in the Laptev Sea close to the shore are higher than the average $\mathrm{PFe}$ concentration in the Lena River but similar to the highest $\mathrm{PFe}$ river values up to $32 \mu \mathrm{M}$ (Hirst et al., 2017b). The CFe and DFe in the Lena River (Hirst et al., 2017b) showed higher average concentrations (CFe: $1.5 \mu \mathrm{M}$; DFe: $54 \mathrm{nM}$ ) than concentrations found in the Lena River-Laptev Sea transect. Most likely some of the $\mathrm{CFe}$ and $\mathrm{DFe}$ from the Lena River already flocculated at salinities below 1, where the first sample of our sampling profile was taken (YS-14). Within the Arctic Ocean, dissolved 
Table 4. Fe-isotope data for the particulate and the colloidal phase as well as $\mathrm{Fe}$-isotope data for the surface sediments.

\begin{tabular}{|c|c|c|c|c|}
\hline \multicolumn{5}{|c|}{ Particulate $>0.22 \mu \mathrm{m}$} \\
\hline Station & $\begin{array}{r}\delta^{56 / 54} \mathrm{Fe} \\
\% \circ\end{array}$ & $\begin{array}{l}2 \sigma \\
\% o\end{array}$ & $\begin{array}{r}\delta^{57 / 54} \mathrm{Fe} \\
\% \circ\end{array}$ & $\begin{array}{l}2 \sigma \\
\% \sigma\end{array}$ \\
\hline $\begin{array}{l}\text { YS-128 } \\
\text { YS-4 } \\
\text { YS-6 } \\
\text { YS-8 } \\
\text { YS-11 } \\
\text { YS-14 }\end{array}$ & $\begin{array}{l}-0.289 \\
-0.406 \\
-0.360 \\
-0.130 \\
-0.067 \\
-0.048\end{array}$ & $\begin{array}{l}0.050 \\
0.126 \\
0.014 \\
0.008 \\
0.040 \\
0.106\end{array}$ & $\begin{array}{l}-0.487 \\
-0.735 \\
-0.644 \\
-0.266 \\
-0.106 \\
-0.097\end{array}$ & $\begin{array}{l}0.024 \\
0.114 \\
0.082 \\
0.136 \\
0.008 \\
0.114\end{array}$ \\
\hline \multicolumn{5}{|c|}{ Colloidal $1 \mathrm{kDa}-0.22 \mu \mathrm{m}$} \\
\hline Station & $\begin{array}{r}\delta^{56 / 54} \mathrm{Fe} \\
\% \circ\end{array}$ & $\begin{array}{l}2 \sigma \\
\% o\end{array}$ & $\begin{array}{r}\delta^{57 / 54} \mathrm{Fe} \\
\% \circ\end{array}$ & $\begin{array}{l}2 \sigma \\
\% o\end{array}$ \\
\hline $\begin{array}{l}\text { YS-128 } \\
\text { YS-4 } \\
\text { YS-11 } \\
\text { YS-14 }\end{array}$ & $\begin{array}{r}0.112 \\
0.102 \\
-0.227 \\
-0.171\end{array}$ & $\begin{array}{l}0.069 \\
0.079 \\
0.089 \\
0.015\end{array}$ & $\begin{array}{r}0.233 \\
0.277 \\
-0.312 \\
-0.267\end{array}$ & $\begin{array}{l}0.050 \\
0.038 \\
0.298 \\
0.030\end{array}$ \\
\hline \multicolumn{5}{|c|}{ Surface sediment } \\
\hline Station & $\begin{array}{r}\delta^{56 / 54} \mathrm{Fe} \\
\% \circ\end{array}$ & $\begin{array}{l}2 \sigma \\
\% \circ\end{array}$ & $\begin{array}{r}\delta^{57 / 54} \mathrm{Fe} \\
\% \circ\end{array}$ & $\begin{array}{l}2 \sigma \\
\% \sigma\end{array}$ \\
\hline $\begin{array}{l}\text { YS-13 } \\
\text { YS-4 } \\
\text { YS-26 } \\
\text { YS-14 } \\
\text { YS-2 } \\
\text { YS-3 } \\
\text { YS-11 } \\
\text { YS-28 } \\
\text { YS-30 } \\
\text { YS-39 }\end{array}$ & $\begin{array}{l}-0.233 \\
-0.220 \\
-0.209 \\
-0.250 \\
-0.351 \\
-0.230 \\
-0.083 \\
-0.131 \\
-0.102 \\
-0.241\end{array}$ & $\begin{array}{l}0.070 \\
0.040 \\
0.002 \\
0.110 \\
0.150 \\
0.024 \\
0.022 \\
0.074 \\
0.028 \\
0.086\end{array}$ & $\begin{array}{l}-0.324 \\
-0.355 \\
-0.298 \\
-0.404 \\
-0.439 \\
-0.396 \\
-0.209 \\
-0.220 \\
-0.185 \\
-0.403\end{array}$ & $\begin{array}{l}0.006 \\
0.028 \\
0.116 \\
0.100 \\
0.102 \\
0.106 \\
0.094 \\
0.118 \\
0.088 \\
0.124\end{array}$ \\
\hline
\end{tabular}

$\mathrm{Fe}(\mathrm{CFe}+\mathrm{DFe})$ concentrations vary between 0.2 and $63 \mathrm{nM}$ and the concentrations depend on distance to the shore and depths of sampling, with generally higher values in surface waters as well as close to the bottom sediment, which might be related to resuspension, sinking of brine, or resuspension from the sedimentary Fe (Klunder et al., 2012; Thuróczy et al., 2011). The CFe concentrations are higher close to the coast and decrease in the outer plume to values that are similar to $\mathrm{CFe}$ concentrations reported from further out in the Arctic Ocean (e.g. Thuróczy et al., 2011). Estuarine processes, including flocculation and sedimentation (e.g. Boyle et al., 1977; Sholkovitz, 1978), are the primary causes for the sharp decrease in particulate and dissolved Fe concentrations along the transect from the river towards the open Arctic Ocean. Within the estuaries, the destabilization of the Ferich colloids and particles by seawater cations causes flocculation along the salinity gradient (Escoube et al., 2009; Gerringa et al., 2007; Mosley et al., 2003) and successively sed- imentation of the newly built flocculates (Daneshvar, 2015). The distribution of Fe between the different phases shows that $\mathrm{PFe}$ is the dominant $\mathrm{Fe}$ phase in the inner plume system (with a $\mathrm{PFe} / \mathrm{CFe}$ ratio of about 90 ). However, most of the $\mathrm{PFe}$ is lost in the inner plume close to the shore and the ratio $\mathrm{PFe} / \mathrm{CFe}$ decreases towards a ratio of about 1 in the outer plume.

We observed non-conservative mixing of PFe at salinities lower than 5 and conservative mixing at salinities higher than 5 (Fig. 5). Recent studies showed that the majority of PFe $(70 \pm 15 \%)$ coming from the Lena River is in the form of chemically reactive ferrihydrite (Hirst et al., 2017b). Organic $\mathrm{C}$ hinders the coagulation of the particles during riverine transport, but in the estuarine mixing zone the negatively charged iron-bearing particles will react with seawater cations and form larger aggregates (Boyle et al., 1977). The larger aggregates sink more readily to the sediments in the Lena River-Laptev Sea transect and can thus explain the observed non-conservative behaviour (Martin et al., 1993). This process is a common feature for Fe that is observed in other estuaries and is responsible for at least $80 \%$ loss of "dissolved" riverine Fe (Boyle et al., 1977; Figuères et al., 1978; Guieu et al., 1996; Windom et al., 1971). The large amount of PFe (99\%) lost in the inner Lena River freshwater plume is likely due to removal of chemically reactive ferrihydrite, which is the main form of PFe in the Lena River. Furthermore, it has been shown that about $20 \%$ of OC in the Eurasian Arctic Shelf is bound to reactive Fe phases (Salvadó et al., 2015). It has also been shown that part of the ferrihydrite might be transported via surface attachment to POC in a network of organic fibrils (Hirst et al., 2017b). The attachment of POC to the ferrihydrite possibly reduces the density of Fe oxyhydroxides (Passow, 2004), allowing both POC and PFe to be transported into the Arctic Ocean, where they are present at about $2 \%$ of their initial concentration in rivers. Concentrations of $\mathrm{PFe}$ at salinities $>5$ and $\mathrm{CFe}$ along the whole salinity gradient show a linear correlation with salinity, suggesting that these particles and colloids are less affected by changes in ionic strength and therefore might be mainly in the form of Fe oxyhydroxides. Gregor et al. (1997) showed that the optimal range for cationic flocculation is a pH between 6 and 7. At a higher $\mathrm{pH}$, more cations are needed for achieve the same efficiency of flocculation. Anyhow, Asmala et al. (2014) showed that the $\mathrm{pH}$ range is important at salinities below 1-2, but at higher salinities the $\mathrm{pH}$ is negligible. Furthermore, they showed that it is likely that high $\mathrm{Fe}$ concentrations are a more significant factor and will yield to the same flocculation rates. The DFe $(<1 \mathrm{kDa})$ concentrations along the freshwater plume are almost constant around $8 \mathrm{nM}$ (except station YS-14, $1 \mathrm{nM}$ ). The average DFe concentration in the Lena River is about $54 \mathrm{nM}$ (Hirst et al., 2017b). These data suggest a loss of DFe at low salinities $(<1.3)$ before the concentration stabilize around $8 \mathrm{nM}$ in the Lena River freshwater plume. These observations are in accordance with previous studies in the Laptev Sea, where 
dissolved Fe concentrations of 3 to $10 \mathrm{nM}$ in the upper $20 \mathrm{~m}$ have been reported (Klunder et al., 2012). It has also been reported that about $74 \%$ to $83 \%$ of the dissolved Fe is present in the truly dissolved phase in the Arctic Ocean (Thuróczy et al., 2011). Slagter et al. (2017) report dissolved Fe concentration of $2.6 \mathrm{nM}$ in the Transpolar Drift, which is transporting surface water from Siberian great rivers, e.g. Lena River, across the Arctic Ocean into the Atlantic. Available evidence indicates that the $\mathrm{Ob}$ River similarly contributes Fe into the open Arctic Ocean. Along the Ob River, the DFe shows relatively constant DFe concentrations of 36 to $44 \mathrm{nM}$ in the $10 \mathrm{kDa}$ fraction (Dai and Martin, 1995), which are somewhat higher than reported here for the Lena, possibly due to a larger ultrafiltration cut-off size. The overall trend of this and earlier studies suggests a loss of DFe from the Lena River to the Lena River freshwater plume and almost constant concentrations along the freshwater plume. The conservative behaviour of DFe concentrations along a salinity gradient has been examined in estuarine mixing experiments, and it has been shown that freshwater Fe oxyhydroxide colloids aggregate into much larger particles in contact with seawater, whereas the truly dissolved phase was virtually unaffected (Gustafsson et al., 2000; Stolpe and Hassellöv, 2007). The observation that the truly dissolved phase is less affected by the increase in salinity suggests that this phase can be transported through estuaries and further out into the open ocean (Laglera and Van Den Berg, 2009).

River water is the most important source of Fe for the central Arctic Ocean (Klunder et al., 2012) and estuarine processes significantly modify the amount and distribution of Fe between different fractions and therefore also the bioavailability of the river-derived Fe. Slomp et al. (2013) showed that $\mathrm{Fe}$ concentrations are likely to affect the sedimentation of organic matter and $\mathrm{P}$ in sediments of lakes and coastal seas. Therefore, the loss of $\mathrm{Fe}-\mathrm{OC}$ aggregates close to the shoreline might also cause a great loss of phosphorous and thus contribute to the suggested "rusty carbon sink" (Lalonde et al., 2012; Salvadó et al., 2015).

\subsection{Iron isotopes in the Lena River freshwater plume}

The measured $\delta^{56} \mathrm{Fe}$ compositions in the Lena River plume are broadly similar to those reported in previous studies in other Arctic/sub-Arctic regions (e.g. Escoube et al., 2009; Staubwasser et al., 2013). In these areas, within the fully oxidized water column, the PFe phase shows negative $\delta^{56} \mathrm{Fe}$ values, while the dissolved phase generally shows values enriched in $\mathrm{Fe}$ (III) compared to the PFe phase (Escoube et al., 2015, 2009; Ingri et al., 2006; Staubwasser et al., 2013; Zhang et al., 2015). It has been shown that the Feisotope composition is affected by seasonal variations in water flow paths to the river (Hirst et al., 2017a). Ingri et al. (2018) showed that the Fe-isotope composition is an indicator of different $\mathrm{Fe}$ aggregates and changing primary $\mathrm{Fe}$ sources throughout the season. Along the freshwater plume the $\mathrm{CFe}$ phase has two different Fe-isotope compositions, positive and negative $\delta^{56} \mathrm{Fe}$ values. Therefore it might also represent water masses from different seasons. This would suggest that the water masses in the inner plume represent spring flood discharge, whereas the water masses in the outer plume represent summer flow discharge. In contrast, Alling et al. (2010), claim that the age of the entire freshwater plume is approximately 2 months. All measured DOC samples (400-420 $\mu \mathrm{M})$ from their study plot on a mixing line of Lena River water measured in August and Arctic deepwater. If the water represented spring flood discharge, which has much higher DOC concentrations $(1170 \mu \mathrm{M})$, their samples would be plotted on a different mixing line (Alling et al., 2010).

Sundman et al. (2014) measured the speciation of Fe in stream water samples with X-ray absorption spectroscopy and found iron-organic complexes with mixed speciation states of $\mathrm{Fe}$ as $\mathrm{Fe}(\mathrm{II}, \mathrm{III})-\mathrm{OC}$ and $\mathrm{Fe}(\mathrm{III})$ oxyhydroxides associated with $\mathrm{OC}$. The variations in the distributions of $\mathrm{Fe}$ between the different species in the iron-organic complexes are controlled by $\mathrm{pH}$ and $\mathrm{OC}$ concentrations (Neubauer et al., 2013; Sundman et al., 2013). The Fe speciation of these complexes regulate the Fe-isotopic composition. When $\mathrm{Fe}(\mathrm{II})$ is oxidized to $\mathrm{Fe}$ (III), the heavy ${ }^{56} \mathrm{Fe}$ is enriched in the $\mathrm{Fe}$ (III) phase, whereas $\mathrm{Fe}$ (II) becomes depleted in the ${ }^{56} \mathrm{Fe}$ isotope (Bullen et al., 2001; Homoky et al., 2012; Rouxel et al., 2008; Severmann et al., 2006; Welch et al., 2003; Wu et al., 2011). Laboratory experiments showed the existence of oxidative precipitation of $\mathrm{Fe}$ (II) to $\mathrm{Fe}(\mathrm{III})$ (e.g. Welch et al., 2003), which can occur in natural streams. Bullen et al. (2001) measured an overall fractionation factor of about 0.9 in natural streams. Hence, Fe(III)oxyhydroxides should show a enrichment of ${ }^{56} \mathrm{Fe}$ in oxidized river water, while $\mathrm{Fe}(\mathrm{II}, \mathrm{III})-\mathrm{OC}$ complexes should show a depletion of ${ }^{56} \mathrm{Fe}$. The differences in the $\mathrm{Fe}$-isotope composition in the $\mathrm{PFe}$ and $\mathrm{CFe}$ fraction clearly indicate different sources for the two phases, as flocculation of $\mathrm{CFe}$ into $\mathrm{PFe}$ would result in PFe with the same isotopic composition (e.g. Escoube et al., 2009). The existence of two different Fe colloid pools, composed of organicrich and Fe-rich particles, was shown by Pokrovsky and Schott (2002) in small boreal rivers. Fe-isotope data from this study show the existence of two colloidal Fe phases with different $\delta^{56} \mathrm{Fe}$ within the Lena River-Laptev Sea transect. The $\mathrm{Fe}$-isotope values of $\mathrm{CFe}$ and $\mathrm{PFe}$ along the plume and the composition of the surface sediment suggest that the chemically reactive ferrihydrite represent colloids and particles, with a negative $\delta^{56} \mathrm{Fe}$ value, sedimenting close to the shoreline. The Fe oxyhydroxides that remain in the water column could then be responsible for the positive $\delta^{56} \mathrm{Fe}$ values in the colloidal phase in the outer plume. Therefore, in this case the Lena River is an important source of positive $\delta^{56} \mathrm{Fe}$ values to the Arctic Ocean, along with small OC-rich Arctic and subArctic rivers (Ilina et al., 2013; Pokrovsky et al., 2014).

The surface sediments in the shelf areas along the Laptev Sea have $\delta^{56} \mathrm{Fe}$ values of $-0.2 \%$ (Fig. 6). This value re- 
sults from the removal of particulate and colloidal Fe(II, III)oxyhydroxides from the water column and burial in the sediment. As seen in earlier studies, flocculation during estuarine mixing did not fractionate the $\mathrm{Fe}$-isotopic composition of the colloids and particles (Bergquist and Boyle, 2006; Escoube et al., 2009; Fantle and DePaolo, 2004; Poitrasson et al., 2014). Other processes, such as resuspension of sediment and non-reductive dissolution of sediment to the seawater (Radic et al., 2011), would lead to a much more negative ( $-3.3 \%$ o to $-1.7 \%$ ) Fe-isotope composition of the sediment (Homoky et al., 2009; Severmann et al., 2006, 2010). Therefore, the $\delta^{56} \mathrm{Fe}$ of the uppermost sediment reflecting the $\delta^{56} \mathrm{Fe}$ of the sedimenting colloids and particles from the water column seems reasonable.

\section{Conclusions}

Close to the coast and within the inner part of the river plume, the concentration of PFe dominates the total $\mathrm{Fe}$ budgets. In the outer part of the plume, the $\mathrm{PFe}$ and $\mathrm{CFe}$ concentrations are almost equal, as more than $99 \%$ of the total $\mathrm{Fe}$ is lost. The loss of PFe, most likely in the form of chemically reactive ferrihydrite, results from increasing ionic strength due to increasing salinities, which promote flocculation. The coagulation and removal appear at the beginning of the mixing zone at low salinities (0-5). Colloidal Fe concentrations are almost constant along the inner plume and decrease along the outer plume due to conservative mixing. The truly dissolved $\mathrm{Fe}$ shows little variation along the Lena River freshwater plume. Therefore, the river-derived truly dissolved fraction could be an important source of bioavailable Fe, along with colloidal $\mathrm{Fe}$, which may affect the primary production in the central Arctic Ocean.

The Fe-isotope compositions in the Lena River freshwater plume provide clear indications of which forms of $\mathrm{Fe}$ reach the deep ocean basin. There are significant differences between the particulate and colloidal phases. The negative $\delta^{56} \mathrm{Fe}$ values, found in the colloidal and particulate phases, are lost during estuarine mixing and buried in the sediment. These negative $\delta^{56} \mathrm{Fe}$ values seem to represent chemically reactive ferrihydrite. Within the colloidal phase, we measured positive $\delta^{56} \mathrm{Fe}$ values further out in the plume, which likely represent $\mathrm{Fe}$ oxyhydroxides, which remain buoyant in the water column, transported along the Lena River freshwater plume into the Arctic Ocean.

Data availability. Data used to generate all figures are available in the paper as tables and in the Supplement. Salinity data used to generate Fig. 2 can be found in the Bolin Centre Database at https: //bolin.su.se (last access: 22 March 2019).

Supplement. The supplement related to this article is available online at: https://doi.org/10.5194/bg-16-1305-2019-supplement.
Author contributions. JG, FN, PSA, DP, ÖG, and IS carried out the field and lab work. EE and IR performed the stable isotope analysis. $\mathrm{SC}$ analysed the data, prepared the figures, and wrote the manuscript under the supervision of JI and with contributions from JG, FN, PSA, EE, OS, DP, ÖG, IS, and BÖ.

Competing interests. The authors declare that they have no conflict of interest.

Acknowledgements. The ISSS-08 programme was supported by the Knut and Alice Wallenberg Foundation, the Far Eastern Branch of the Russian Academy of Sciences, the Swedish Research Council (621-2004-4039 and 211-621-2007), the U.S. National Oceanic and Atmospheric Administration, the Russian Foundation for Basic Research, the Swedish Polar Research Secretariat, and the Stockholm University Bert Bolin Centre for Climate Research. Örjan Gustafsson also acknowledge a Distinguished Professor Grant from the Swedish Research Council (VR contract no. 2017-05687), an advanced grant from the European Research Council (ERC-AdG CCTOP project \#695331). Igor Semiletov acknowledges the Russian Government (14.Z50.31.0012) and the Russian Scientific Foundation (15-17-20032). The ISSS-08 programme is part of the IPY (International Polar Year) and the GEOTRACES programme.

Review statement. This paper was edited by Aninda Mazumdar and reviewed by two anonymous referees.

\section{References}

Allard, T., Menguy, N., Salomon, J., Calligaro, T., Weber, T., Calas, G., and Benedetti, M. F.: Revealing forms of iron in river-borne material from major tropical rivers of the Amazon Basin (Brazil), Geochim. Cosmochim. Ac., 68, 3079-3094, https://doi.org/10.1016/J.GCA.2004.01.014, 2004.

Alling, V., Sanchez-Garcia, L., Porcelli, D., Pugach, S., Vonk, J. E., Van Dongen, B., Mörth, C. M., Anderson, L. G., Sokolov, A., Andersson, P., Humborg, C., Semiletov, I., and Gustafsson, Ö.: Nonconservative behavior of dissolved organic carbon across the Laptev and East Siberian seas, Global Biogeochem. Cy., 24, 115, https://doi.org/10.1029/2010GB003834, 2010.

Alling, V., Porcelli, D., Mörth, C. M., Anderson, L. G., SanchezGarcia, L., Gustafsson, Ö., Andersson, P. S., and Humborg, C.: Degradation of terrestrial organic carbon, primary production and out-gassing of $\mathrm{CO}_{2}$ in the Laptev and East Siberian Seas as inferred from $\delta^{13} \mathrm{C}$ values of DIC, Geochim. Cosmochim. Ac., 95, 143-159, https://doi.org/10.1016/j.gca.2012.07.028, 2012.

Amon, R. M. W., Rinehart, A. J., Duan, S., Louchouarn, P., Prokushkin, A., Guggenberger, G., Bauch, D., Stedmon, C., Raymond, P. A., Holmes, R. M., McClelland, J. W., Peterson, B. J., Walker, S. A., and Zhulidov, A. V.: Dissolved organic matter sources in large Arctic rivers, Geochim. Cosmochim. Ac., 94, 217-237, https://doi.org/10.1016/j.gca.2012.07.015, 2012.

Anbar, A. D.: Iron stable isotopes: Beyond biosignatures, Earth Planet. Sc. Lett., 217, 223-236, https://doi.org/10.1016/S0012821X(03)00572-7, 2004. 
Andersson, L. and Jutterstrøm, S.: Seawater carbonate chemistry and nutrients measured on water bottle samples during the International Siberian Shelf Study 2008 (ISSS-08) in the Laptev, East Siberian and Chukchi Seas, Department of Chemistry, University of Gothenburg, PANGAEA, https://doi.org/10.1594/PANGAEA.715045, 2008.

Anderson, L. G., Jutterstrøm, S., Hjalmarsson, S., Wåhlström, I., and Semiletov, I. P.: Out-gassing of $\mathrm{CO}_{2}$ from Siberian Shelf seas by terrestrial organic matter decomposition, Geophys. Res. Lett., 36, L20601, https://doi.org/10.1029/2009GL040046, 2009.

Anisimov, O. and Reneva, S.: Permafrost and Changing Climate: The Russian Perspective, AMBIO, 35, 169-175, https://doi.org/10.1579/00447447(2006)35[169:PACCTR]2.0.CO;2, 2006.

Antonov, V. S.: The Mouth Area of the Lena, in: The Hydrographic Review, Gidrometeoizdat, Leningrad, 1967.

Asmala, E., Bowers, D., Autio, R., Kaartokallio, H., and Thomas, D. N.: Qualitative changes of riverine dissolved organic matter at low salinities due to flocculation, J. Geophy. Res.-Biogeo., 119, 1919-1933, https://doi.org/10.1002/2014JG002722, 2014.

Baxter, D. C., Rodushkin, I., Engström, E., and Malinovsky, D.: Revised exponential model for mass bias correction using an internal standard for isotope abundance ratio measurements by multi-collector inductively coupled plasma mass spectrometry, J. Anal. Atom. Spectrom., 21, 427-430, https://doi.org/10.1039/b517457k, 2006.

Beard, B. L. and Johnson, C. M.: Ancient Earth and Other Planetary Bodies, Rev. Mineral., 55, 319-357, https://doi.org/10.2138/gsrmg.55.1.319, 2004.

Beard, B. L., Johnson, C. M., Cox, L., Sun, H., Nealson, K. H., and Aguilar, C.: Iron isotope biosignatures, Science, 285, 18891891, https://doi.org/10.1126/science.285.5435.1889, 1999.

Beard, B. L., Johnson, C. M., Von Damm, K. L., and Poulson, R. L.: Iron isotope constraints on Fe cycling and mass balance in oxygenated Earth oceans, Geology, 31, 629-632, https://doi.org/10.1130/00917613(2003)031<0629:IICOFC>2.0.CO;2, 2003.

Bergquist, B. A. and Boyle, E. A.: Iron isotopes in the Amazon River system: Weathering and transport signatures, Earth Planet. Sc. Lett., 248, 39-53, https://doi.org/10.1016/j.eps1.2006.05.004, 2006.

Boyle, E. A., Edmond, J. M., and Sholkovitz, E. R.: The mechanism of iron removal in estuaries, Geochim. Cosmochim. Ac., 41, 1313-1324, https://doi.org/10.1016/0016-7037(77)90075-8, 1977.

Brantley, S. L., Liermann, L., and Bullen, T. D.: Fractionation of $\mathrm{Fe}$ isotopes by soil microbes and organic acids, Geology, 29, 535-538, https://doi.org/10.1130/00917613(2001)029<0535:FOFIBS>2.0.CO;2, 2001.

Bröder, L., Tesi, T., Salvadó, J. A., Semiletov, I. P., Dudarev, O. V., and Gustafsson, Ö.: Fate of terrigenous organic matter across the Laptev Sea from the mouth of the Lena River to the deep sea of the Arctic interior, Biogeosciences, 13, 5003-5019, https://doi.org/10.5194/bg-13-5003-2016, 2016.

Bullen, T. D., White, A. F., Childs, C. W., Vivit, D. V., and Schultz, M. S.: Demonstration of a significant iron isotope fractionation in nature, Geology, 29, 699-702, https://doi.org/10.1130/00917613(2001)029<0699:DOSAII>2.0.CO;2, 2001.
Cauwet, G. and Sidorov, I.: The biogeochemistry of Lena River: organic carbon and nutrients distribution, Mar. Chem., 53, 211 227, https://doi.org/10.1016/0304-4203(95)00090-9, 1996.

Chester, R.: Marine geochemistry, 2nd Edn., Blackwell Pub, Malden, 2003.

Conway, T. M. and John, S. G.: Quantification of dissolved iron sources to the North Atlantic Ocean, Nature, 511, 212-215, https://doi.org/10.1038/nature13482, 2014.

Cutter, G., Andersson, P., Codispoti, L., Croot, P., Francois, R., Lohan, M., van der Loeff, M. R.: Sampling and sample handling protocol for GEOTRACES cruises, Version 1.0, available at: http://www.geotraces.org/science/intercalibration/ 222-sampling-and-sample-handling-protocols-for-geotraces-cruises (last access: 22 March 2019), 2010.

Dai, M.-H. and Martin, J.-M.: First data on trace metal level and behaviour in two major Arctic river-estuarine systems $(\mathrm{Ob}$ and Yenisey) and in the adjacent Kara Sea, Russia, Earth Planet. Sc. Lett., 131, 127-141, https://doi.org/10.1016/0012821X(95)00021-4, 1995.

Daneshvar, E.: Dissolved Iron Behavior in the Ravenglass Estuary Waters, An Implication on the Early Diagenesis, Universal Journal of Geoscience, 3, 1-12, https://doi.org/10.13189/ujg.2015.030101, 2015.

de Baar, H. J. W. and de Jong, J. T. M.: Distributions, sources and sinks of iron in seawater, in: Biogeochemistry of Iron in Seawater, edited by: Turner, D. R. and Hunter, K. A., Wiley, New York, 123-253, 2001.

Dos Santos Pinheiro, G. M., Poitrasson, F., Sondag, F., Cochonneau, G., and Vieira, L. C.: Contrasting iron isotopic compositions in river suspended particulate matter: The Negro and the Amazon annual river cycles, Earth Planet. Sc. Lett., 394, 168178, https://doi.org/10.1016/j.epsl.2014.03.006, 2014.

Dudarev, O.: Cruise report International Siberian Shelf Study 2008 (ISSS-08), Swedish Knut and Alice Wallenberg Foundation, the Far-Eastern Branch of the Russian Academy of Sciences, the Swedish Research Councli, the Russian Foundation for Basic Research, NoAA, and the Swedish Polar Research Secretariat, Bremerhaven, PANGAEA Documentation, Hdl:10013/epic32714, 2008.

Eckert, J. M. and Sholkovitz, E. R.: The flocculation of iron, aluminum and humates from river water by electrolytes, Geochim. Cosmochim. Ac., 40, 847-848, 1976.

Escoube, R., Rouxel, O. J., Sholkovitz, E., and Donard, O. F. X.: Iron isotope systematics in estuaries: The case of North River, Massachusetts (USA), Geochim. Cosmochim. Ac., 73, 40454059, https://doi.org/10.1016/j.gca.2009.04.026, 2009.

Escoube, R., Rouxel, O. J., Pokrovsky, O. S., Schroth, A., Max Holmes, R., and Donard, O. F. X.: Iron isotope systematics in Arctic rivers, CR Geosci., 347, 377-385, https://doi.org/10.1016/j.crte.2015.04.005, 2015.

Fantle, M. S. and DePaolo, D. J.: Iron isotopic fractionation during continental weathering, Earth Planet. Sc. Lett., 228, 547-562, https://doi.org/10.1016/j.epsl.2004.10.013, 2004.

Figuères, G., Martin, J. M., and Meybeck, M.: Iron behaviour in the Zaire Estuary, Neth. J. Sea Res., 12, 329-337, 1978.

Forsberg, J., Dahlqvist, R., Gelting-Nyström, J., and Ingri, J.: Trace metal speciation in brackish water using diffusive gradients in thin films and ultrafiltration: compari- 
son of techniques, Environ. Sci. Technol., 40, 3901-3905, https://doi.org/10.1021/es0600781, 2006.

Gerringa, L. J. A., Rijkenberg, M. J. A., and Wolterbeek, H. Th., Verburg, T. G., Boye, M., and de Abar, H. J. W.: Kinetic study reveals weak Fe-binding ligand, which affects the solubility of Fe in the Scheldt estuary, Mar. Chem., 103, 30-45, https://doi.org/10.1016/j.marchem.2006.06.002, 2007.

Gregor, J. E., Nokes, C. J., and Fenton, E.: Optimising natural organic matter removal from low turbidity waters by controlled pH adjustment of aluminium coagulation, Water Res., 31, 29492958, 1997.

Guieu, C., Huang, W. W., Martin, J. M., and Yong, Y. Y.: Outflow of trace metals into the Laptev Sea by the Lena River, Mar. Chem., 53, 255-267, https://doi.org/10.1016/03044203(95)00093-3, 1996.

Guo, L. and Santschi, P.: A critical evaluation of cross-flow ultrafiltration technique for sampling colloidal organic carbon in seawater, Mar. Chem., 55, 113-127, https://doi.org/10.1016/S03044203(96)00051-5, 1996.

Gustafsson, C. and Gschwend, P. M.: Aquatic colloids: Concepts, definitions, and current challenges, Limnol. Oceanogr., 42, 519528, https://doi.org/10.4319/lo.1997.42.3.0519, 1997.

Gustafsson, Ö., Widerlund, A., Andersson, P. S., Ingri, J., Roos, P., and Ledin, A.: Colloid dynamics and transport of major elements through a boreal river - Brackish bay mixing zone, Mar. Chem., 71, 1-21, https://doi.org/10.1016/S03044203(00)00035-9, 2000.

Hirst, C., Andersson, P., Mörth, M., Kutscher, L., Murphy, M., Schmitt, M., Petrov, R., Maximov, T., and Porcelli, D.: Seasonal Variations in the Sources and Formation of Fe-Bearing Particles in the Lena River Basin; Evidence from Iron Isotopes, Goldschmidt Abstracts, 1643, available at: https://goldschmidtabstracts.info/abstracts/abstractView?id= 2017004101 (last access: 22 March 2019), 2017a.

Hirst, C., Andersson, P. S., Shaw, S., Burke, I. T., Kutscher, L., Murphy, M. J., Maximov, T., Pokrovsky, O. S., Mörth, C. M., and Porcelli, D.: Characterisation of Fe-bearing particles and colloids in the Lena River basin, NE Russia, Geochim. Cosmochim. Ac., 213, 553-573, https://doi.org/10.1016/j.gca.2017.07.012, 2017b.

Holmes, R. M., McClelland, J. W., Peterson, B. J., Tank, S. E., Bulygina, E., Eglinton, T. I., Gordeev, V. V., Gurtovaya, T. Y., Raymond, P. A., Repeta, D. J., Staples, R., Striegl, R. G., Zhulidov, A. V., and Zimov, S. A.: Seasonal and Annual Fluxes of Nutrients and Organic Matter from Large Rivers to the Arctic Ocean and Surrounding Seas, Estuar. Coast., 35, 369-382, https://doi.org/10.1007/s12237-011-9386-6, 2012.

Homoky, W. B., Severmann, S., Mills, R. A., Statham, P. J., and Fones, G. R.: Proe-fluid Fe isotopes reflect the extent of benthic $\mathrm{Fe}$ redoc recycling: Evidence from continental shelf and deep-sea sediments, Geology, 37, 751-754, https://doi.org/10.1130/G25731A.1, 2009.

Homoky, W. B., Severmann, S., McManus, J., Berelson, W. M., Riedel, T. E., Statham, P. J., and Mills, R. A.: Dissolved oxygen and suspended particles regulate the benthic flux of iron from continental margins, Mar. Chem., 134-135, 59-70, https://doi.org/10.1016/j.marchem.2012.03.003, 2012.

Icopini, G. A., Anbar, A. D., Ruebush, S. S., Tien, M., and Brantley, S. L.: Iron isotope fractionation during microbial reduction of iron: The importance of adsorption, Geology, 32, 205-208, https://doi.org/10.1130/G20184.1, 2004.

Ilina, S. M., Poitrasson, F., Lapitskiy, S. A., and Alekhin, Y. V.: Extreme iron isotope fractionation between different size colloids of boreal organic-rich waters, Geochim. Cosmochim. Ac., 101, 96-111, https://doi.org/10.1016/j.gca.2012.10.023, 2013.

Ingri, J., Widerlund, A., Land, M., Gustafsson, Ö., Andersson, P., and Öhlander, B.: Temporal variations in the fractionation of the rare earth elements in a Boreal river; the role of colloidal particles, Chem. Geol., 166, 23-45, https://doi.org/10.1016/S00092541(99)00178-3, 2000.

Ingri, J., Malinovsky, D., Rodushkin, I., Baxter, D. C., Widerlund, A., Andersson, P., Gustafsson, Ö., Forsling, W., and Öhlander, B.: Iron isotope fractionation in river colloidal matter, Earth Planet. Sc. Lett., 245, 792-798, https://doi.org/10.1016/j.eps1.2006.03.031, 2006.

Ingri, J., Conrad, S., Lidman, F., Nordblad, F., Engström, E., Rodushkin, I., and Porcelli, D.: Iron isotope pathways in the boreal landscape: Role of the riparian zone, Geochim. Cosmochim. Ac., 239, 49-60, https://doi.org/10.1016/j.gca.2018.07.030, 2018.

Karlsson, E., Gelting, J., Tesi, T., van Dongen, B., Andersson, A., Semiletov, I., Charkin, A., Dudarev, O., and Gustafsson, Ö.: Different sources and degradation state of dissolved, particulate, and sedimentary organic matter along the Eurasian Arctic coastal margin, Global Biogeochem. Cy., 30, 898-919, https://doi.org/10.1002/2015GB005307, 2016.

Klunder, M. B., Bauch, D., Laan, P., De Baar, H. J. W., Van Heuven, S., and Ober, S.: Dissolved iron in the Arctic shelf seas and surface waters of the central Arctic Ocean: Impact of Arctic river water and ice-melt, J. Geophys. Res.-Oceans, 117, 1-18, https://doi.org/10.1029/2011JC007133, 2012.

Kritzberg, E. S., Villanueva, A. B., Jung, M., and Reader, H. E.: Importance of boreal rivers in providing iron to marine waters, PLoS One, 9, e107500, https://doi.org/10.1371/journal.pone.0107500, 2014.

Kutscher, L., Mörth, C. M., Porcelli, D., Hirst, C., Maximov, T. C., Petrov, R. E., and Andersson, P. S.: Spatial variation in concentration and sources of organic carbon in the Lena River, Siberia, J. Geophys. Res.-Biogeo., 122, 1999-2016, https://doi.org/10.1002/2017JG003858, 2017.

Laglera, L. M. and Van Den Berg, C. M. G.: Evidence for geochemical control of iron by humic substances in seawater, Limnol. Oceanogr., 54, 610-619, https://doi.org/10.4319/lo.2009.54.2.0610, 2009.

Lalonde, K., Mucci, A., Ouellet, A., and Gélinas, Y.: Preservation of organic matter in sediments promoted by iron, Nature, 483, 198-200, https://doi.org/10.1038/nature10855, 2012.

Larsson, J., Ingri, J., and Gustafsson, Ö.: Evaluation and optimization of two complementary cross-flow ultrafiltration systems toward isolation of coastal surface water colloids, Environ. Sci. Technol., 36, 2236-2241, https://doi.org/10.1021/ES010325V, 2002.

Le Fouest, V., Babin, M., and Tremblay, J.-É.: The fate of riverine nutrients on Arctic shelves, Biogeosciences, 10, 3661-3677, https://doi.org/10.5194/bg-10-3661-2013, 2013.

Martin, J. H., Gordon, R. M., and Fitzwater, E. S.: Iron Limitation?, Limnol. Oceanogr., 36, 1793-1802, https://doi.org/10.4319/lo.1991.36.8.1793, 1991. 
Martin, J. M. and Meybeck, M.: Elemental mass-balance or material carried by major world rivers, Mar. Chem., 7, 173-206, 1979.

Martin, J. M., Guan, D. M., Elbazpoulichet, F., Thomas, A. J., and Gordeev, V. V.: Preliminary Assessment of the Distributions of Some Trace-Elements (as, $\mathrm{Cd}, \mathrm{Cu}, \mathrm{Fe}, \mathrm{Ni}, \mathrm{Pb}$ and $\mathrm{Zn}$ ) in a Pristine Aquatic Environment - the Lena River Estuary (Russia), Mar. Chem., 43, 185-199, https://doi.org/10.1016/03044203(93)90224-C, 1993.

Mosley, L. M., Hunter, K. A., and Ducker, W. A.: Forces between colloid particles in natural waters, Environ. Sci. Technol., 37, 3303-3308, https://doi.org/10.1021/es026216d, 2003.

Mulholland, D. S., Poitrasson, F., Boaventura, G. R., Allard, T., Vieira, L. C., Santos, R. V., Mancini, L., and Seyler, P.: Insights into iron sources and pathways in the Amazon River provided by isotopic and spectroscopic studies. Geochim. Cosmochim. Ac., 150, 142-159, https://doi.org/10.1016/j.gca.2014.12.004, 2015.

Neubauer, E., Köhler, S. J., Von Der Kammer, F., Laudon, H., and Hofmann, T.: Effect of $\mathrm{pH}$ and stream order on iron and arsenic speciation in boreal catchments, Environ. Sci. Technol., 47, 7120-7128, https://doi.org/10.1021/es401193j, 2013.

Ödman, F., Ruth, T., and Pontér, C.: Validation of a field filtration technique for characterization of suspended particulate matter from freshwater. Part I. Major elements, Appl. Geochem., 14, 301-317, https://doi.org/10.1016/S0883-2927(98)00050-X, 1999.

Opsahl, S., Benner, R., and Amon, R. M. W.: Major flux of terrigenous dissolved organic matter through the Arctic Ocean, Limnol. Oceanogr., 44, 2017-2023, https://doi.org/10.4319/lo.1999.44.8.2017, 1999.

Passow, U.: Switching perspectives: Do mineral fluxes determine particulate organic carbon fluxes or vice versa?, Geochem. Geophy. Geosy., 5, Q04002, https://doi.org/10.1029/2003GC000670, 2004.

Pédrot, M., Le Boudec, A., Davranche, M., Dia, A., and Henin, O.: How does organic matter constrain the nature, size and availability of Fe nanoparticles for biological reduction?, J. Colloid Interf. Sci., 359, 75-85, https://doi.org/10.1016/j.jcis.2011.03.067, 2011.

Perdue, E. M., Beck, K. C., and Reuter, J. H.: Organic complexes of iron and aluminium in natural waters, Nature, 260, 418-420, https://doi.org/10.1038/260418a0, 1976.

Pipko, I. I., Pugach, S. P., Semiletov, I. P., Anderson, L. G., Shakhova, N. E., Gustafsson, Ö., Repina, I. A., Spivak, E. A., Charkin, A. N., Salyuk, A. N., Shcherbakova, K. P., Panova, E. V., and Dudarev, O. V.: The spatial and interannual dynamics of the surface water carbonate system and air-sea $\mathrm{CO}_{2}$ fluxes in the outer shelf and slope of the Eurasian Arctic Ocean, Ocean Sci., 13, 997-1016, https://doi.org/10.5194/os-13-997-2017, 2017.

Poitrasson, F.: On the iron isotope homogeneity level of the continental crust, Chem. Geol., 235, 195-200, https://doi.org/10.1016/j.chemgeo.2006.06.010, 2006.

Poitrasson, F. and Freydier, R.: Heavy iron isotope composition of granites determined by high resolution MC-ICP-MS, Chem. Geol., 222, 132-147, https://doi.org/10.1016/j.chemgeo.2005.07.005, 2005.

Poitrasson, F., Cruz Vieira, L., Seyler, P., Márcia dos Santos Pinheiro, G., Santos Mulholland, D., Bonnet, M. P., Martinez, J. M., Alcantara Lima, B., Resende Boaventura, G., Chmeleff, J. Ô., Dantas, E. L., Guyot, J. L., Mancini, L., Martins
Pimentel, M., Ventura Santos, R., Sondag, F., and Vauchel, P.: Iron isotope composition of the bulk waters and sediments from the Amazon River Basin, Chem. Geol., 377, 1-11, https://doi.org/10.1016/j.chemgeo.2014.03.019, 2014.

Pokrovsky, O. S. and Schott, J.: Iron colloids/organic matter associated transport of major and trace elements in small boreal rivers and their estuaries (NW Russia), Chem. Geol., 190, 141-179, https://doi.org/10.1016/S0009-2541(02)00115-8, 2002.

Pokrovsky, O. S., Schott, J., and Dupré, B.: Trace element fractionation and transport in boreal rivers and soil porewaters of permafrost-dominated basaltic terrain in Central Siberia, Geochim. Cosmochim. Ac., 70, 3239-3260, https://doi.org/10.1016/j.gca.2006.04.008, 2006.

Pokrovsky, O. S., Viers, J., Shirokova, L. S., Shevchenko, V. P., Filipov, A. S., and Dupré, B.: Dissolved, suspended, and colloidal fluxes of organic carbon, major and trace elements in the Severnaya Dvina River and its tributary, Chem. Geol., 273, 136-149, https://doi.org/10.1016/j.chemgeo.2010.02.018, 2010.

Pokrovsky, O. S., Shirokova, L. S., Zabelina, S. A., Vorobieva, T. Ya., Moreva, O. Yu., Klimov, S. I., Chupakov, A. V., Shorina, N. V., Kokryatskaya, N. M., Audry, S., Viers, J., Zoutien, C., and Freydier, R.: Size fractionation of trace elements in a seasonally stratified boreal lake: control of organic matter and iron colloids, Aquat. Geochem., 18, 115-139, https://doi.org/10.1007/s10498011-9154-z, 2012.

Pokrovsky, O. S., Shirokova, L. S., Viers, J., Gordeev, V. V., Shevchenko, V. P., Chupakov, A. V., Vorobieva, T. Y., Candaudap, F., Causserand, C., Lanzanova, A., and Zouiten, C.: Fate of colloids during estuarine mixing in the Arctic, Ocean Sci., 10, 107-125, https://doi.org/10.5194/os-10-107-2014, 2014.

Poulton, S. W. and Raiswell, R.: Chemical and physical characteristics of iron oxides in riverine and glacial meltwater sediments, Chem. Geol., 218, 203-221, https://doi.org/10.1016/j.chemgeo.2005.01.007, 2005.

Pugach, S. P., Pipko, I. I., Shakhova, N. E., Shirshin, E. A., Perminova, I. V., Gustafsson, Ö., Bondur, V. G., Ruban, A. S., and Semiletov, I. P.: Dissolved organic matter and its optical characteristics in the Laptev and East Siberian seas: spatial distribution and interannual variability (2003-2011), Ocean Sci., 14, 87-103, https://doi.org/10.5194/os-14-87-2018, 2018.

Rachold, V., Alabyan, A., Hubberten, H.-W., Korotaev, V. N., and Zaitsev, A. A.: Sediment transport to the Laptev Sea-hydrology and geochemistry of the Lena River, Polar Res., 15, 183-196, https://doi.org/10.3402/polar.v15i2.6646, 1996.

Radic, A., Laca, F., and Murray, J. W.: Iron isotopes in the seawater of the equatorial Pacif Ocean: New constraints for the oceanic iron cycle, Earth Planet. Sc. Lett., 306, 1-10, https://doi.org/10.1016/j.epsl.2011.03.015, 2011.

Raiswell, R. and Canfield, D. E.: The Iron Biogeochemical Cycle Past and Present, Geochem. Perspect, 1, 1-220, https://doi.org/10.7185/geochempersp.1.1, 2012.

Raymond, P. A., McClelland, J. W., Holmes, R. M., Zhulidov, A. V., Mull, K., Peterson, B. J., Striegl, R. G., Aiken, G. R., and Gurtovaya, T. Y.: Flux and age of dissolved organic carbon exported to the Arctic Ocean: A carbon isotopic study of the five largest arctic rivers, Global Biogeochem. Cy., 21, 1-9, https://doi.org/10.1029/2007GB002934, 2007.

Rodushkin, I. and Ruth, T.: Determination of Trace Metals in Estuarine and Sea-water Reference Materials by High Resolution 
Inductively Coupled Plasma Mass Spectrometry, J. Anal. Atom. Spectrom., 12, 1181-1185, https://doi.org/10.1039/a702486j, 1997.

Rodushkin, I., Nordlund, P., Engström, E., and Baxter, D. C.: Improved multi-elemental analyses by inductively coupled plasma-sector field mass spectrometry through methane addition to the plasma, J. Anal. Atom. Spectrom., 20, 1250-1255, https://doi.org/10.1039/b507886e, 2005.

Rodushkin, I., Engström, E., and Baxter, D.: Sources of contamination and remedial strategies in the multi-elemental trace analysis laboratory, Anal. Bioanal. Chem., 396, 365-377, https://doi.org/10.1007/s00216-009-3087-z, 2010.

Rodushkin, I., Pallavicini, N., Engström, E., Sörlin, D., Öhlander, B., Ingri, J., and Baxter, D. C.: Assessment of the natural variability of $\mathrm{B}, \mathrm{Cd}, \mathrm{Cu}, \mathrm{Fe}, \mathrm{Pb}, \mathrm{Sr}, \mathrm{Tl}$, and $\mathrm{Zn}$ concentrations and isotopic compositions in leaves, needles, and mushrooms using single sample digestion and two-column matrix separation, J. Anal. Atom. Spectrom., 31, 220-233, https://doi.org/10.1039/C5JA00274E, 2016.

Rosén, P.-O., Andersson, P. S., Alling, V., Mörth, C.-M., Björk, G., Semiletov, I., and Porcelli, D.: Ice export from the Laptev and East Siberian Sea derived from $\delta^{18} \mathrm{O}$ values, J. Geophys. Res.-Oceans, 120, 5997-6007, https://doi.org/10.1002/2015JC010866, 2015.

Rouxel, A., Bekker, K. J., and Edwards, O. J.: Iron isotope constraints on the Archaen and Paleoproterozoic Ocean redox state, Science, 307, 1088-1091, 2005.

Rouxel, O., Sholkovitz, E., Charette, M., and Edwards, K. J.: Iron isotope fractionation in subterranean estuaries, Geochim. Cosmochim. Ac., 72, 3413-3430, https://doi.org/10.1016/j.gca.2008.05.001, 2008.

Salvadó, J. A., Tesi, T., Andersson, A., Ingri, J., Dudarev, O. V., Semiletov, I. P., and Gustafsson, Ö.: Organic carbon remobilized from thawing permafrost is resequestered by reactive iron on the Eurasian Arctic Shelf, Geophys. Res. Lett., 42, 8122-8130, https://doi.org/10.1002/2015GL066058, 2015.

Salvadó, J. A., Bröder, L., Andersson, A., Semiletov, I. P., and Gustafsson, Ö.: Release of black carbon from thawing permafrost estimated by sequestration fluxes in the East Siberian Arctic Shelf recipient, Global Biogeochem. Cy., 31, 1501-1515, https://doi.org/10.1002/2017GB005693, 2017.

Sánchez-García, L., Alling, V., Pugach, S., Vonk, J., Van Dongen, B., Humborg, C., Dudarev, O., Semiletov, I., and Gustafsson, Ö.: Inventories and behavior of particulate organic carbon in the Laptev and East Siberian seas, Global Biogeochem. Cy., 25, 113, https://doi.org/10.1029/2010GB003862, 2011.

Semiletov, I. P., Pipko, I. I., Shakhova, N. E., Dudarev, O. V., Pugach, S. P., Charkin, A. N., McRoy, C. P., Kosmach, D., and Gustafsson, Ö.: Carbon transport by the Lena River from its headwaters to the Arctic Ocean, with emphasis on fluvial input of terrestrial particulate organic carbon vs. carbon transport by coastal erosion, Biogeosciences, 8, 2407-2426, https://doi.org/10.5194/bg-8-2407-2011, 2011.

Severmann, S., Johnson, C. M., Beard, B. L., and McManus, J.: The effect of early diagenesis on the Fe isotope compositions of porewaters and authigenic minerals in continental margin sediments, Geochim. Cosmochim. Ac., 70, 2006-2022, https://doi.org/10.1016/J.GCA.2006.01.007, 2006.
Severmann, S., McManus, J., Berelson, W. M., and Hammond, D. E.: The continental shelf benthic iron flux and its isotope composition, Geochim. Cosmochim. Ac., 74, 3984-4004, https://doi.org/10.1016/j.gca.2010.04.022, 2010.

Sholkovitz, E. R.: Floculation of dissolved organic and inorganic matter during the mixing of river water and seawater, Geochim. Cosmochim. Ac., 40, 831-845, 1976.

Sholkovitz, E. R.: The flocculation of dissolved Fe, Mn, Al, Cu, Ni, Co and Cd during estuarine mixing, Earth Planet. Sc. Lett., 41, 77-86, https://doi.org/10.1016/0012-821X(78)90043-2, 1978.

Skulan, J. L., Beard, B. L., and Johnson, C. M.: Kinetic and equilibrium $\mathrm{Fe}$ isotope fractionation between aqueous $\mathrm{Fe}(\mathrm{III})$ and hematite, Geochim. Cosmochim. Ac., 66, 2995-3015, https://doi.org/10.1016/S0016-7037(02)00902-X, 2002.

Slagter, H. A., Reader, H. E., Rijkenberg, M. J. A., Rutgers van der Loeff, M., De Baar, H. J. W. W., Gerringa, L. J. A., Salvadó, J. A., Tesi, T., Andersson, A., Ingri, J., Dudarev, O. V., Semiletov, I. P., Gustafsson, Ö., Kutscher, L., Mörth, C. M., Porcelli, D., Hirst, C., Maximov, T. C., Petrov, R. E., Andersson, P. S., Klunder, M. B., Bauch, D., Laan, P., De Baar, H. J. W. W., Van Heuven, S., Ober, S., Forsberg, J., Dahlqvist, R., Gelting-Nyström, J., Ingri, J., Pokrovsky, O. S., Shirokova, L. S., Viers, J., Gordeev, V. V., Shevchenko, V. P., Chupakov, A. V., Vorobieva, T. Y., Candaudap, F., Causserand, C., Lanzanova, A., and Zouiten, C.: Trace metal speciation in brackish water using diffusive gradients in thin films and ultrafiltration: comparison of techniques, J. Geophys. Res.-Biogeo., 40, 8122-8130, https://doi.org/10.1016/j.marchem.2017.10.005, 2017.

Slomp, C. P., Mort, H. P., Jilbert, T., Reed, D. C., Gustafsson, B. G., and Wolthers, M.: Coupled dynamics of iron and phosphorous in sediments of an oligotrophic coastal basin and the impact of anaerobic oxidation of methane, PLoS ONE, 8, e62386, https://doi.org/10.1371/journal.pone.0062386, 2013.

Staubwasser, M., Schoenberg, R., von Blanckenburg, F., Krüger, S., and Pohl, C.: Isotope fractionation between dissolved and suspended particulate $\mathrm{Fe}$ in the oxic and anoxic water column of the Baltic Sea, Biogeosciences, 10, 233-245, https://doi.org/10.5194/bg-10-233-2013, 2013.

Stolpe, B. and Hassellöv, M.: Changes in size distribution of fresh water nanoscale colloidal matter and associated elements on mixing with seawater, Geochim. Cosmochim. Ac., 71, 3292-3301, https://doi.org/10.1016/j.gca.2007.04.025, 2007.

Stolpe, B., Guo, L., and Shiller, A. M.: Binding and transport of rare earth elements by organic and iron-rich nanocolloids in alaskan rivers, as revealed by field-flow fractionation and ICP-MS, Geochim. Cosmochim. Ac., 106, 446-462, https://doi.org/10.1016/j.gca.2012.12.033, 2013.

Sundman, A., Karlsson, T., and Persson, P.: An experimental protocol for structural characterization of $\mathrm{Fe}$ in dilute natural waters, Environ. Sci. Technol., 47, 8557-8564, https://doi.org/10.1021/es304630a, 2013.

Sundman, A., Karlsson, T., Laudon, H., and Persson, P.: XAS study of iron speciation in soils and waters from a boreal catchment, Chem. Geol., 364, 93-102, https://doi.org/10.1016/j.chemgeo.2013.11.023, 2014.

Tagliabue, A., Bopp, L., Dutay, J.-C., Bowie, A. R., Chever, F., Jean-Baptiste, P., Bucciarelli, E., Lannuzel, D., Remenyi, T., Sarthou, G., Aumont, O., Gehlen, M., and Jeandel, C.: Hydrothermal contribution to the oceanic dissolved iron inven- 
tory, Nat. Geosci., 3, 252-256, https://doi.org/10.1038/ngeo818, 2010.

Tagliabue, A., Bowie, A. R., Boyd, P. W., Buck, K. N., Johnson, K. S., and Saito, M. A.: The integral role of iron in ocean biogeochemistry, Nature, 543, 51-59, https://doi.org/10.1038/nature21058, 2017.

Thuróczy, C.-E., Gerringa, L. J. A., Klunder, M., Laan, P., Le Guitton, M., and de Baar, H. J. W.: Distinct trends in the speciation of iron between the shallow shelf seas and the deep basins of the Arctic Ocean, J. Geophys. Res., 116, C10009, https://doi.org/10.1029/2010JC006835, 2011.

Tipping, E.: The adsorption of aquatic humic substances by iron oxides. Geochim. Cosmochim. Ac., 45, 191-199, https://doi.org/10.1016/0016-7037(81)90162-9, 1981.

Vonk, J. E., van Dongen, B. E., and Gustafsson, Ö.: Selective preservation of old organic carbon fluvially released from sub-Arctic soils, Geophys. Res. Lett., 37, L11605, https://doi.org/10.1029/2010GL042909, 2010.

Vonk, J. E., Sánchez-García, L., van Dongen, B. E., Alling, V., Kosmach, D., Charkin, A., Semiletov, I. P., Dudarev, O. V., Shakhova, N., Roos, P., Eglinton, T. I., Andersson, A., and Gustafsson, Ö.: Activation of old carbon by erosion of coastal and subsea permafrost in Arctic Siberia, Nature, 489, 137-140, https://doi.org/10.1038/nature11392, 2012.

Wagner, V.: Analysis of a Russian landscape map and landscape classification for use in computer-aided forestry research, IIASA Interim Report IR-97-54.56, International Institute for Applied Systems Analysis, Laxenburg, 1997.

Walter, H. and Breckle, S.-W.: Walter's Vegetation of the earth?: the ecological systems of the geo-biosphere, Springer-Verlag, Berlin Heidelberg, 2002.

Wedepohl, K. H.: INGERSON LECTURE The composition of the continental crust, Geochim. Cosmochim. Ac., 59, 1217-1232, https://doi.org/10.1016/0016-7037(95)00038-2, 1995.
Welch, S. A., Beard, B. L., Johnson, C. M., and Braterman, P. S.: Kinetic and equilibrium $\mathrm{Fe}$ isotope fractionation between aqueous $\mathrm{Fe}(\mathrm{II})$ and $\mathrm{Fe}(\mathrm{III})$, Geochim. Cosmochim. Ac., 67, 4231-4250, https://doi.org/10.1016/S0016-7037(03)00266-7, 2003.

Wiederhold, J. G., Kraemer, S. M., Teutsch, N., Borer, P. M., Halliday, A. N., and Kretzschmar, R.: Iron isotope fractionation during proton-promoted, ligand-controlled, and reductive dissolution of goethite, Environ. Sci. Technol., 40, 3787-3793, https://doi.org/10.1021/es052228y, 2006.

Windom, H. L., Beck, K., and Smith, R.: Transport of trace metals to the Atlantic Ocean by three southeastern rivers, Southeast Geol., 12, 169-181, 1971.

Wu, L., Beard, B. L., Roden, E. E., and Johnson, C. M.: Stable Iron Isotope Fractionation Between Aqueous $\mathrm{Fe}(\mathrm{II})$ and Hydrous Ferric Oxide, Environ. Sci. Technol., 45, 1847-1852, https://doi.org/10.1021/es103171x, 2011.

Yang, D., Kane, D. L., Hinzman, L. D., Zhang, X., Zhang, T., and Ye, H.: Siberian Lena River hydrologic regime and recent change, J. Geophys. Res.-Atmos., 107, ACL14-1-ACL14-10, https://doi.org/10.1029/2002JD002542, 2002.

Zhang, F., Zhu, X., Yan, B., Kendall, B., Peng, X., Li, J., Algeo, T. J., and Romaniello, S.: Oxygenation of a Cryogenian ocean (Nanhua Basin, South China) revealed by pyrite Fe isotope compositions, Earth Planet. Sc. Lett., 429, 11-19, https://doi.org/10.1016/J.EPSL.2015.07.021, 2015.

Zhang, T., Barry, R. G., Knowles, K., Heginbottom, J. A., and Brown, J.: Statistics and characteristics of permafrost and ground-ice distribution in the Northern Hemisphere, Polar Geogr., 23, 132-154, https://doi.org/10.1080/10889379909377670, 1999. 